DIW BERLIN

Discussion

Papers
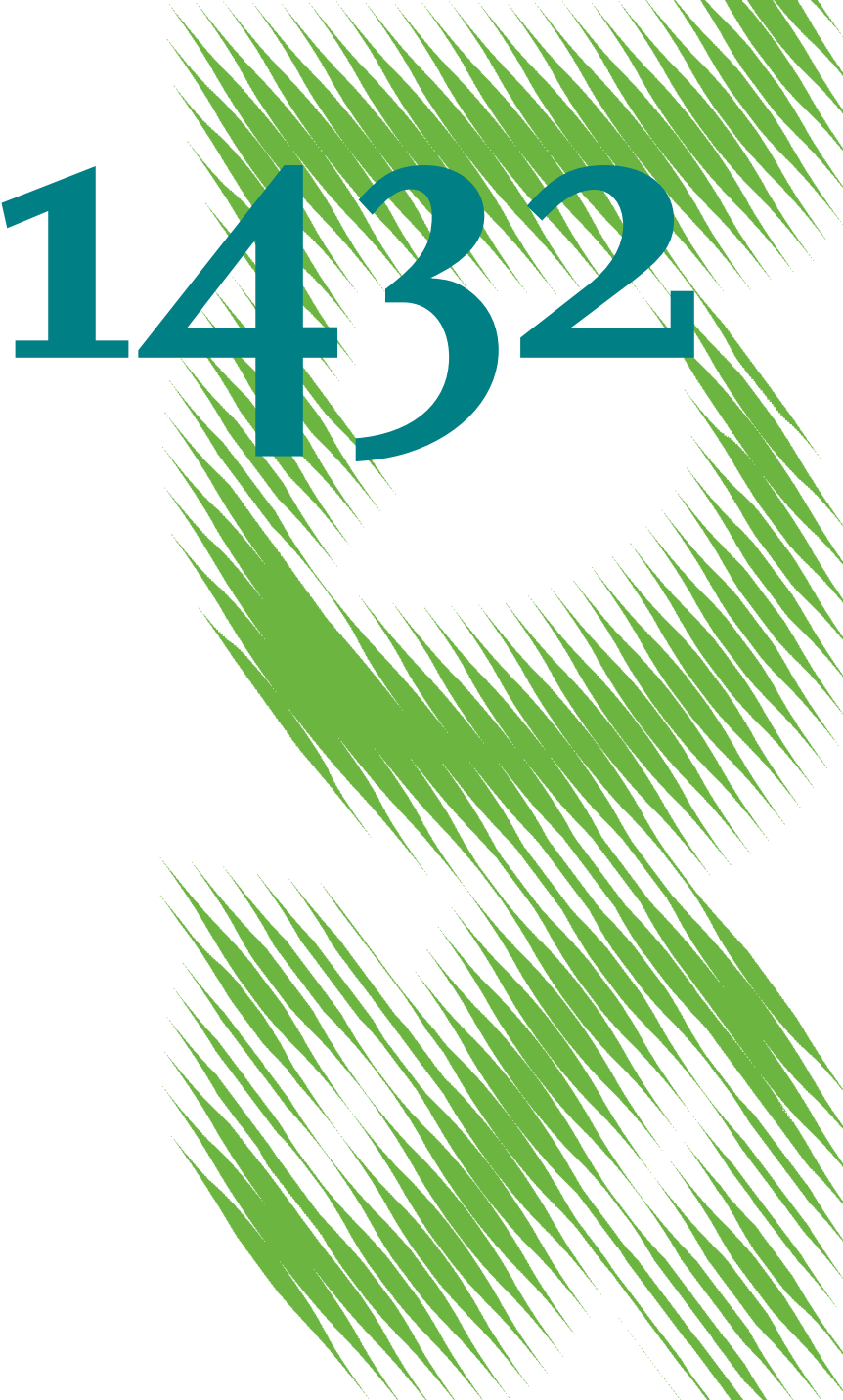

MIMIMIMMMMM

Career Prospects and Effort Incentives: Evidence from Professional Soccer 
Opinions expressed in this paper are those of the author(s) and do not necessarily reflect views of the institute.

IMPRESSUM

(C) DIW Berlin, 2014

DIW Berlin

German Institute for Economic Research

Mohrenstr. 58

10117 Berlin

Tel. +49 (30) $89789-0$

Fax +49 (30) $89789-200$

http://www.diw.de

ISSN electronic edition 1619-4535

Papers can be downloaded free of charge from the DIW Berlin website:

http://www.diw.de/discussionpapers

Discussion Papers of DIW Berlin are indexed in RePEc and SSRN:

http://ideas.repec.org/s/diw/diwwpp.html

http://www.ssrn.com/link/DIW-Berlin-German-Inst-Econ-Res.html 


\title{
Career Prospects and Effort Incentives: Evidence from Professional Soccer*
}

\author{
Jeanine Miklós-Thal ${ }^{\dagger} \quad$ Hannes Ullrich $^{\ddagger}$
}

\begin{abstract}
It is difficult to test the prediction that future career prospects create implicit effort incentives because researchers cannot randomly "assign" career prospects to economic agents. To overcome this challenge, we use data from professional soccer, where employees of the same club face different external career opportunities depending on their nationality. We test whether the career prospect of being selected to a Euro Cup national team affects players' pre-Cup performances, using nationals of countries that did not participate in the Euro Cup as a control group. We find that the Euro Cup career prospect has positive effects on the performances of players with intermediate chances of being selected to their national team, but negative effects on the performances of players whose selection is very probable. Our findings have implications for the incentive effects of within-firm promotions and of external career opportunities.
\end{abstract}

JEL: D23, L29, M52

Keywords: incentives, effort, career concerns, reputation, contests, tournaments, promotions

\footnotetext{
${ }^{*}$ We are grateful to Nicolas Berman, Jen Brown, Luís Cabral, Gregorio Caetano, Florian Ederer, Christos Genakos, Ulrich Kaiser, Alexander Koch, Mitch Lovett, Ryan McDevitt, Minjung Park, Michael Raith, Thomas Rønde, Stephen Ryan, Stephan Seiler, Minjae Song, Birger Wernerfelt, and audiences at Amsterdam, ESSEC, Ecole Polytechnique, European University Institute, Frankfurt, Mannheim, MIT, Rochester, Tilburg, Zurich, the Armand Caraben workshop at IESE, the 2009 European Economic Association meeting, the 2011 Royal Economic Society annual conference, and the 2013 Tournaments, Contests and Relative Performance Evaluation Conference at UC Merced for helpful comments. Lukas Kornher and Cem Ermagan provided valuable research assistance. Financial support by the Leibniz Association, the ZEW Mannheim, and the Swiss National Science Foundation (grant PBZHP1-143346) is gratefully acknowledged.

${ }^{\dagger}$ Simon Graduate School of Business, University of Rochester - jeanine.miklosthal@simon.rochester.edu

$\ddagger$ Department Firms and Markets, DIW Berlin and Department of Business Administration, University of Zurich - hannes.ullrich@business.uzh.ch
} 



\section{Introduction}

Economists and management scholars have long argued that many incentives arise not through formal contracts but implicitly through career concerns (Fama 1980). According to the theory of implicit incentives (Holmström 1982/1999, Dewatripont et al. 1999a, 1999b), economic agents exert effort in the hope of building a reputation for high ability that pays off in the future. Even in the absence of any explicit incentive contracts, such as pay-for-performance schemes, economic agents may thus work hard in order to improve their future promotion and employment opportunities.

Although the premise that implicit incentives drive decisions is widely accepted, it is difficult to test empirically. Ideally, empirical research would randomly "assign" future career prospects, such as the opportunity to get promoted to a better paid job, in order to test their impact. However, researchers can hardly preclude a random subset of employees from future promotions or external employment opportunities. Most existing empirical studies of implicit incentives therefore focus on comparative statics results of dynamic career concerns models, mainly with respect to seniority (Gibbons and Murphy 1992, Chevalier and Ellison 1999, Hong et al. 2000). In contrast, this paper considers a situation close to the ideal of randomly assigned career prospects in order to provide direct evidence that career prospects create effort incentives. More specifically, we analyze a work environment in which a major career prospect arises for only a subset of otherwise similar employees of the same set of firms - professional soccer.

Every four years, national soccer teams from across Europe compete in the so-called Euro Cup, participation in which represents a major career opportunity for any player 1 Prior to each Euro Cup, the national team coaches of all participating countries must select a fixed number of players for their Euro Cup teams. National team coaches can select only nationals of the country that their team represents, unlike professional clubs, which employ players of many different nationalities. An exogenous characteristic, nationality, thus determines whether a player can be selected to a Euro Cup team, regardless of where he is employed. This nationality rule allows us to estimate the effects that the career prospect of being selected to a Euro Cup team has on players' performances by comparing players of different nationalities before and during the Euro Cup national team player selection period. Importantly, all players we consider work in the same national

\footnotetext{
${ }^{1}$ As we will discuss in more detail, players care about participating in the Euro Cup for both pecuniary (national team bonus payments, endorsement deals, improved salary and employment prospects after the Cup) and non-pecuniary (honor, fame) reasons.
} 
league and therefore face similar career incentives unrelated to national teams.

To guide our empirical analyses, we propose a simple game-theoretical model of the rivalry between players for national team slots that combines learning about ability à la Holmström (1982/1999) with a tournament à la Lazear and Rosen (1981). In the model, an attractive position is awarded to the agent perceived as the most able. Each agent can exert effort to increase his expected performance, thereby "jamming the signal" that the decision-maker uses to update his beliefs about the agent's ability. The model also incorporates fatigue by assuming that an agent's payoff from winning is decreasing in his effort during the selection period. The key theoretical predictions are (i) that contest participation has a positive effect on the effort of an agent with an intermediate winning chances, but (ii) that, due to fatigue concerns, contest participation has a negative effect on the efforts of an agent with a high enough winning chance.2

To test these predictions, we use a detailed panel data set of player-level performances in the First Division of the German Soccer League ("1. Bundesliga") in the two seasons leading up the 2008 Euro Cup. The performance measures fall into two categories. First, observable outputs such as shots on goal and ball contacts. Second, performance grades assigned to players by sports magazines after each game. Since theory predicts that the incentive effects of the Euro Cup career prospect differ between players with different chances of being selected, we also use data on past national team selections to predict players' selection chances ${ }^{3}$ This allows us to investigate how the effect of the Euro Cup career prospect varies with selection chance. The detailed panel data permit inclusion of player fixed effects in all regressions, thereby controlling for skill differences between players.

Consistent with our theoretical predictions, we find that the Euro Cup career prospect had positive and economically significant effects on the performances of players with intermediate chances of being selected for their national team. The estimated increase in the number of ball contacts for a player with intermediate chances, for instance, is $16 \%$. For players with very good chances, we find economically important negative effects on performance. The estimated decrease in the number of ball contacts is $-19 \%$. As mentioned earlier, negative effects are to be expected if players with almost certain selection chances make it their priority to avoid fatigue and injuries prior to the Euro Cup. Finally, we

\footnotetext{
${ }^{2}$ Adding the risk of an injury that jeopardize the agent's promotion to the attractive position to the model generates similar negative incentive effects for agents with high winning chances as fatigue.

${ }^{3}$ National teams play occasional friendly matches and qualification matches for Cups during the regular season and coaches can select different players for each of these matches.
} 
find no impact of the Euro Cup career prospect treatment on the performances of players without any (or only very few) prior national team appearances, which is again consistent with our theoretical predictions.

These findings have implications beyond the world of professional sports. In particular, soccer players from qualified European nations find themselves in a situation bearing close resemblance to that of employees facing future promotion prospects. First, in both situations the decision-maker's goal is to select the most able agents; hence, agents have incentives to exert effort in order to impress the decision-maker. 4 Second, in many firms the number of available promotions is restricted due to technological or organizational factors (O'Keeffe et al. 1984, Waldman 2013), as is the number of slots on the national team. Employees thus compete against their peers in a contest in which relative perceived abilities determine who gets promoted. Third, while physical injuries are of less concern in white-collar occupations than in sports, there is growing evidence that fatigue due to overwork has detrimental effects on future productivity and decision-making ability (Harrison and Horne 2000, Galinsky et al. 2005).5

Employees who hope to obtain a promotion thus have incentives to increase or reduce effort for similar reasons as the soccer players in our data. Our empirical findings suggest that effort incentives due to the promotion prospect will be strong for employees who perceive that they have intermediate chances of getting promoted. Employees with very good chances of being promoted in the near future, on the other hand, may actually reduce their effort relative to a situation without any promotion prospect.

One would expect the latter effect to be particularly relevant in professions such as management consulting and law, where career concerns are a major driver of incentives. Junior consultants and law associates often work long hours and suffer from sleep deprivation (Landers et al. 1996, Ferrer 2008). Moreover, promotions are typically coupled with more responsibility and larger projects. An employee who is confident that she will be promoted in the near future may therefore rationally decide to "take it easy" for a while in order to be well rested for the new tasks ahead.

\footnotetext{
${ }^{4}$ More generally, promotions may serve two functions: (i) sorting by ability, and (ii) incentive provision. However, whenever promotions are coupled with assignments to jobs in which ability matters more, it is (ex post) optimal for a firm to promote the agents with the highest perceived abilities (Rosen 1982, Waldman 1984, Ghosh and Waldman 2010).

${ }^{5}$ Some recent models of multi-round tournaments explicitly incorporate the adverse impact of current effort on future performance, either by letting past effort affect success probabilities (Ryvkin 2011) or by imposing a total effort budget across multiple tournament rounds (Harbaugh and Klumpp 2005, Matros 2006).
} 
The remainder of this paper proceeds as follows. Section 2 discusses the related literature. Section 3 presents the theory used to predict that the treatment effect depends on a player's selection chance. Section 4 discusses the institutional background and the data. Section 5 presents the empirical approach and contains the main results; Section 5.1 sets out how we rank players by selection chance; Section 5.2 contains our main findings on the impact of the Euro Cup career prospect for players with different selection chances, employing a variety of empirical approaches; Section 5.3 takes a closer look at various dimensions of player performance, including measures of destructive effort. Section 6 discusses the empirical strategy and several robustness checks. Section 7 concludes.

\section{Related literature}

This paper is related to several strands of the literature. First, it contributes to the empirical literature on implicit incentives by providing direct evidence that future career prospects can have (positive or negative) effects on performance. Existing studies in economics have found evidence consistent with various predictions of dynamic career concerns models by comparing workers of different seniority. Gibbons and Murphy (1992) find that the contracts offered to US executives have more explicit pay-for-performance provisions as workers get closer to retirement. ${ }^{6}$ Chevalier and Ellison (1999) and Hong et al. (2000) show that current performance is more predictive of rewards for younger fund managers and security analysts, respectively, than for their older counterparts and that young managers are less likely to take bold actions.7 A related literature in accounting focuses on the implicit incentive effects of internal promotions. In a study of fast-food retail managers, Campbell (2008) finds that a higher ex ante probability of promotion is associated with improvements in service quality. Ederhof (2011) provides evidence that explicit incentives are stronger for mid-level managers with lower promotion probabilities and concludes that explicit and implicit incentives are substitutes.

Second, our paper relates to the literature on tournaments, because players compete for a limited number of national team slots. Using data from a dynamic tournament among the retailers of a commodities manufacturer, Casas-Arce and Asis Martinez-Jerez

\footnotetext{
${ }^{6}$ Implicit and explicit incentives are substitutes in models where effort and ability enter the production function additively. However, as shown by Dewatripont et al. (1999a), explicit and implicit incentives can be complements if effort and ability enter the production function multiplicatively.

${ }^{7}$ More recent contributions in economics include Coupé et al. (2006) who find that academic economists tend to be more productive early in their careers, and Hansen (2009) who finds that teachers with shorter tenure take fewer sick days.
} 
(2009) find that effort incentives are strongest for retailers with intermediate positions and weakest for retailers with very high or low winning chances. Similarly, Brown (2011) shows that superstar Tiger Woods' participation in golf tournaments adversely affects the performances of his rivals, which is consistent with effort incentives being stronger for players with intermediate chances than for players with low chances. 8

Several important differences to our work are worth pointing out. First, these studies deal with tournaments designed to elicit effort or provide entertainment for an audience. National team coaches, on the other hand, have as their main goal to select the best players, similar to employers who seek to promote high ability agents to tasks in which ability matters more? Second, unlike our setting, which allows us to compare the evolutions of performances of contest participants (players from nations that participate in the Euro Cup) and non-participants (players from nations that do not participate in the Euro Cup) to estimate the impact of contest participation, existing studies of tournaments are restricted to tournament participants. Third, in contrast to these existing contributions, we find that contest participation can have negative incentive effects.

Finally, other studies have used soccer data to study decision-making and test economic theory. Chiappori et al. (2002) and Palacios-Huerta (2003) analyze penalty kicks to test the theory of mixed-strategy play. Garicano and Palacios-Huerta (2014) use data from the Spanish soccer league to show that higher prize differentials increase not only productive but also destructive effort (fouls) in a tournament 10 Miguel et al. (2011) find a relationship between the extent of civil conflict in a player's home country and violent behavior on the field. Although they explore a very different question than our paper, their approach is related to ours in that it exploits the international compositions of professional teams. Similarly, Kleven et al. (2013) exploits that the job market for players is

\footnotetext{
${ }^{8}$ Sunde (2009), Nieken and Stegh (2010), and Franke (2012) also use data from sports tournaments (tennis, hockey, and golf, respectively) to examine the relation between the heterogeneity of contestants and effort. Earlier empirical work on tournaments focuses on whether larger prize differentials induce higher effort. Ehrenberg and Bognanno (1990) and Orszag (1994) provide evidence from golf tournaments, Becker and Huselid (1992) look at auto racing, and Knoeber and Thurman (1995) examine the impact of tournament-style contracts in the broiler industry.

${ }^{9}$ Although promotions in firms are often modeled as tournaments, a tournament based on observed performances cannot replicate a contest based on perceived abilities unless all agents are perfectly symmetric. First, the decision-maker will not necessarily want to promote the agent who performs best during the contest if that agent starts out with a low initial perceived ability. Second, imposing a handicap on players with low initial perceived abilities (as in O'Keefe et al. 1984 or Meyer 1991, 1992) does not suffice to re-establish equivalence to a performance tournament, because it ignores that the decision-maker may update his beliefs about different agents' abilities at different rates depending on his prior information.

${ }^{10} \mathrm{We}$ find that the Euro Cup career prospect leads to less destructive effort by players with high national team selection chances - see Section 5.3.2.
} 
international to analyze the impact of tax rates on migration decisions.

\section{Theory}

Suppose there are two agents (for instance, employees of the same firm or soccer players of the same nationality) competing for an attractive position (a promotion to a better paid job or a slot on the national team) awarded at the end of a fixed time period. The decision is made by a principal (the employer or national team coach) whose objective is to select the most skillful agent.

Our theoretical model combines a tournament à la Lazear and Rosen (1981) with learning about ability as in Holmström (1982/1999). Let $\eta_{j}$ denote agent $j$ 's $(j \in\{1,2\})$ skill level, which is constant over the relevant time period. The principal and the agents share the same prior beliefs. Specifically, the prior $\eta_{j}$ follows a normal distribution with mean $m_{j}$ and precision (equal to the inverse of the variance) $h_{j}>0$. The prior distributions of $\eta_{1}$ and $\eta_{2}$ are independent. Learning about $\eta_{j}$ occurs through the observation of $j$ 's performance. For simplicity, we consider learning in a single time period, in which agent $j$ 's output is given by

$$
y_{j}=\eta_{j}+a_{j}+\varepsilon_{j},
$$

where $a_{j} \in[0, \infty)$ is $j$ 's effort, unobservable to the principal and agent $k \neq j{ }^{11} \varepsilon_{j}$ is a stochastic noise term, where $\varepsilon_{1}$ and $\varepsilon_{2}$ follow independent normal distributions with mean zero and precision $h_{\varepsilon}>0$.

The principal's objective is to select the most skillful agent. After observing $y_{1}$ and $y_{2}$ the principal will hence select $j \neq k$ whenever

$$
E\left[\eta_{j} \mid y_{j}\right]>E\left[\eta_{k} \mid y_{k}\right]
$$

The (expected) prize that $j$ receives if the principal selects him is $W\left(a_{j}\right)>0$. Due to fatigue, current effort weakly lowers expected future performance and thereby the prize: $W^{\prime} \leq 0$

\footnotetext{
${ }^{11}$ In the soccer team selection context, unobservable effort can be thought of as motivation and concentration during matches and training, lifestyle choices (nutrition, sleeping,...), and the intensity of training activities that are unobservable to the national team coach.

${ }^{12}$ For technical reasons, we also assume that effort reduces the prize from winning at a decreasing rate $\left(W^{\prime \prime} \geq 0\right)$ and that $W^{\prime}(0)$ is finite.
} 
The expected payoff of agent $j \neq k \in\{1,2\}$ is

$$
\operatorname{Pr}\left\{E\left[\eta_{j} \mid y_{j}\right]>E\left[\eta_{k} \mid y_{k}\right]\right\} W\left(a_{j}\right)+S_{j}\left(a_{j}\right)-c_{j}\left(a_{j}\right)
$$

where $S_{j}\left(a_{j}\right)$ is $j$ 's expected gross payoff in the absence of the contest and $c_{j}\left(a_{j}\right)$ his disutility of effort. We assume that $S_{j}\left(a_{j}\right)-c_{j}\left(a_{j}\right)$ is strictly concave and reaches its unique maximum at

$$
a_{j}^{n}>0
$$

the "normal" effort level of player $j \in\{1,2\}$. Moreover, $\lim _{a \rightarrow 0} S_{j}^{\prime}(a)-c_{j}^{\prime}(a)=\infty$.

The formal derivation of the Bayesian Nash equilibrium and the comparative statics of the equilibrium effort levels $\left(a_{1}^{*}, a_{2}^{*}\right)$ with are relegated to Online Appendix A. The main results are as follows:

Proposition 1 Suppose that the expected payoff function is strictly concave. Then there exists a unique Bayesian Nash equilibrium with $a_{1}^{*}, a_{2}^{*}>0$. For all $j=1,2,{ }^{13}$

(i) $\lim _{m_{j} \rightarrow-\infty} a_{j}^{*}=a_{j}^{n}$.

(ii) $\lim _{m_{j} \rightarrow \infty} a_{j}^{*}=a_{j}^{n}$ if $W^{\prime}\left(a_{j}^{n}\right)=0$, and $\lim _{m_{j} \rightarrow \infty} a_{j}^{*}<a_{j}^{n}$ if $W^{\prime}\left(a_{j}^{n}\right)<0$.

(iii) There exists a unique $\widehat{m}_{j} \leq m_{k}$ such that $\frac{d a_{j}^{*}}{d m_{j}}>(<) 0$ if and only if $m_{j}<(>) \widehat{m}_{j}$. If $W^{\prime}=0$ everywhere, then $\widehat{m}_{j}=m_{k}$. If $W^{\prime}<0$ everywhere, then $\widehat{m}_{j}<m_{k}$.

Figure 1 depicts the equilibrium relation between agent 1's winning probability and effort as his prior reputation $m_{1}$ varies in a numerical example. The horizontal line indicates the normal effort level $a_{1}^{n}$ the player would exert in the absence of the contest. The equilibrium effort is increasing in the agent's equilibrium winning probability at low winning chances, but decreasing at high winning chances. Moreover, because the agent is concerned with avoiding fatigue, the equilibrium effort lies below $a_{1}^{n}$ if agent 1 's equilibrium winning probability is sufficiently close to 1 and reaches its maximum at a winning chance below 0.5 .14

\footnotetext{
${ }^{13}$ The equilibrium effort levels depend only on the difference $m_{1}-m_{2}$, not on $m_{1}$ and $m_{2}$ individually. All of the results in Proposition 1 could be expressed as comparative statics with respect to $m_{j}-m_{k}$ instead of $m_{j}$.

${ }^{14}$ Injury concerns are another reason why agents with high winning chances may want to exert lower than normal effort. Formally, the model with fatigue is equivalent to a model with injury risk if $W(a)=$ $W[1-r(a)]$ where $W>0$ is a fixed prize and the agent's injury risk is the increasing function $r(a) \in$ $[0,1)$. A small difference between the two models arises if each agent also anticipates that he might get
} 


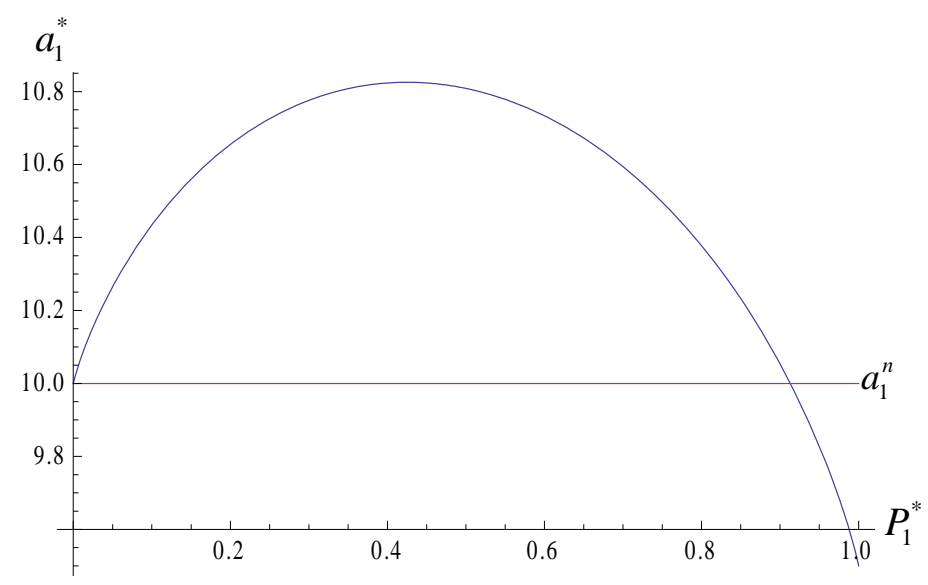

Figure 1: Equilibrium relation between agent 1's effort level $a_{1}^{*}$ and his winning probability $P_{1}^{*}$. $W(a)=10-.5 a$ for $a<18$ and $W(a)=1$ for $a \geq 18, m_{2}=1, h_{1}=h_{2}=2, h_{\varepsilon}=1$, $S_{j}(a)-c_{j}(a)=10 a-\frac{a^{2}}{2}$ for $j=1,2$.

In summary, the theoretical model yields the following predictions regarding the effort incentives of soccer players that compete for national team slots:

1. The prospect of being selected to play for the national team has a negligible impact on the effort incentives of players with weak chances of being selected.

2. The prospect of being selected to play for the national team has a positive impact on the effort incentives of players with intermediate chances of being selected.

3. The prospect of being selected to play for the national team has a negative impact on the effort incentives of players with high chances of being selected if fatigue and/or injury concerns are important, and a negligible impact otherwise.

\section{Institutional background and data}

\subsection{Institutional background}

Professional soccer players are employed by soccer clubs under fixed-term contracts at negotiated salaries. When a player moves between clubs, his old contract is terminated and a new one negotiated; moves prior to contract expiration require the player's new

selected because the other agent is injured, even if the other agent has a higher perceived ability. Now the incentive to reduce effort can also arise for an underdog who has a winning chance close to zero conditional on his opponent remaining injury-free. However, the underdog's incentive to reduce effort is much smaller than that of an agent with a winning probability close to 1 (conditional on no injuries) as an injury by the frontrunner affects the contest outcome with a higher probability. 
club to pay a transfer fee to his current club 15 The job market for professional soccer players is international and many players work outside their home country.

In addition to playing for his club, a player can be selected to play for his national team in international tournaments during national league summer breaks and in occasional (friendly or tournament-qualification) games throughout the year. National teams differ from clubs in that only nationals of the country that the team represents can play for them. The most important international tournaments between national teams are the UEFA European Championship (or Euro Cup) and the FIFA World Cup, which each take place every four years.

There are at least three reasons why participating in a Euro Cup represents a major career prospect for any player. First, there are direct pecuniary rewards to playing in a Euro Cup. Most national associations award bonus payments (based on team performance) to national team players ${ }^{16}$ In addition, a Euro Cup participation often leads to lucrative endorsement deals for players: for example, the Euro 2008 witnessed an advertising battle between Adidas and Nike, both featuring key national team players in their TV commercials. ${ }^{17}$ Second, previous research (Lucifora and Simmons 2003; Frick 2006, 2007; Deutscher and Simmons 2012) has shown that Euro and World Cup participations are associated with subsequent increases in salary and transfers to higher ranked clubs ${ }^{18}$ Third, there are non-pecuniary rewards in the form of fame and honor that probably matter a great deal to many players. ${ }^{19}$

Our empirical analyses will focus on players who worked for clubs in the First Division German soccer league (1. Bundesliga) in the time period between the end of the 2006 World Cup (July 9, 2006) and the end of the 2007/08 soccer season on May 17, 2008. The 2008 Euro Cup, also called Euro 2008, started on June 7, 2008. The Bundesliga is well suited for our purposes, because it was the best represented national league in the

\footnotetext{
${ }^{15}$ Mechanisms such as player drafts, free agent pools, or player trades, which are common in US major sports leagues, do not exist.

${ }^{16}$ Each player selected for the German team was promised 250,000 euros for winning the Euro 2008, 50,000 euros for reaching the final eight, 100,000 euros for the semi-finals and 150,000 euros for getting to the final. The Romanian football federation, with the help of a wealthy club owner, offered 500,000 euros per player if Romania reached the quarter-finals and 5.5 million euros if they won the tournament. See Ashdown, Lay, and Nutbrown (June 18, 2008), "Who are the worst European Championship hosts ever?" The Guardian.

${ }^{17}$ See Jack Edwing (June 20, 2008), "Adidas vs. Nike: Battle of the Soccer Ads," Bloomberg Businessweek.

${ }^{18}$ For a discussion of this in the popular press, see Mark Scott (June 20, 2008), "Star Players Boost Worth in Soccer Cup," Bloomberg Businessweek.

${ }^{19}$ The final of the Euro 2008 between Spain and Germany drew an estimated TV audience of 237 million, and a successful Cup often propels players to celebrity status in their home countries.
} 
Euro 2008. As illustrated in Figure 2, the qualification matches for the Euro 2008 began shortly after the 2006 World Cup. All fifty eligible European national teams participated in them. The qualification period ended on November 21, 2007, but some teams already qualified de facto before that date after having won sufficiently many matches: a group of four countries (Czech Republic, Germany, Greece, and Romania) qualified about one month before the official date, on either the 13th or 17th of October, while ten other nations qualified on the 17 th or 21 st of November. The two remaining participants were Austria and Switzerland, the host nations, which participate automatically.

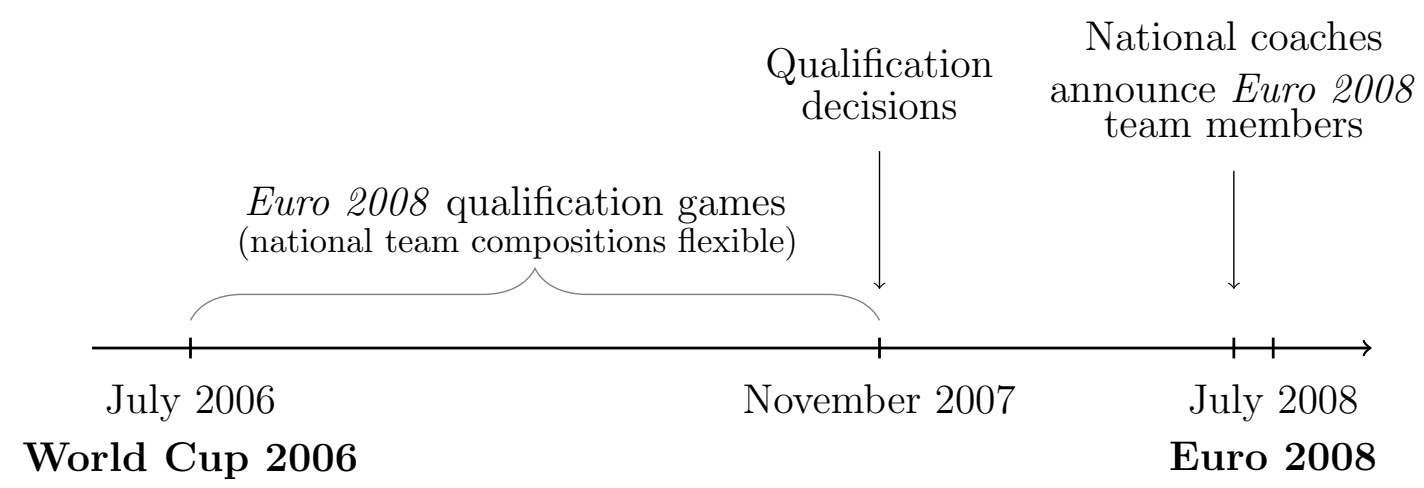

Figure 2: Timeline

For the Euro 2008, each national team coach had to select a fixed roster of 23 players. The deadline for the coaches' announcements of their team selections was eleven days after the end of the $07 / 08$ German soccer season, and the large majority of coaches announced their decisions after the last game day or between the last two game days of the season.

\subsection{Data}

We use a panel data set that contains detailed player-game day level information about the German Soccer League (1. Bundesliga) in the seasons 2006/07 and 2007/08 ${ }^{20}$ For each of the 612 games during the sample period, the data contain individual output measures for all players that were either on the field or on the reserve bench 21 We matched this data set with data about individual injuries collected by the online fantasy soccer website comunio.de. In addition, we collected data on all national team participations of players

\footnotetext{
${ }^{20}$ The data was kindly provided by IMIPRE AG, a company specialized in collecting and selling soccer data.

${ }^{21}$ On average, Bundesliga teams employ 29 players. 11 players are on the field at any given point in a game, and the maximum number of player substitutions per game is 3 .
} 
in our sample between summer 2005 and the Euro 2008 using publicly available sources ${ }^{22}$

\subsubsection{Player sample}

The full Bundesliga data set contains 767 players accounting for a total of 21,906 observations at the player-game day level. We restrict attention to players for whom we have observations before and after the official Euro 2008 qualification date (Nov. 21, 2007) and in each of the two seasons in the sample period, and for whom at least one output observation is strictly positive. Moreover, we dropped observations of goalkeepers (83 players), because they have different tasks than field players and many of our output measures do not apply to them. Finally, we excluded the 21 players from the Euro 2008 host nations Austria and Switzerland, as their national teams were already (automatically) qualified for the Euro 2008 at the beginning of the sample period. The final number of players is 225 and the total number of observations is $11,316.23$

Table 1: Number of players by nationality

\begin{tabular}{|c|c|c|c|c|c|c|c|}
\hline euro & & & & non-eur & & & \\
\hline Czech Republic & 8 & Albania & 2 & Egypt & 1 & Namibia & 1 \\
\hline Croatia & 6 & Algeria & 1 & Finland & 1 & Nigeria & 1 \\
\hline France & 2 & Argentina & 5 & Georgia & 1 & Paraguay & 2 \\
\hline Germany & 108 & Australia & 2 & Ghana & 1 & Peru & 1 \\
\hline Greece & 3 & Belgium & 3 & Guinea & 1 & Serbia & 3 \\
\hline Netherlands & 5 & Bosnia-Herzegovina & 3 & Hungary & 2 & Slovakia & 3 \\
\hline Poland & 5 & Brazil & 17 & Iran & 2 & South Africa & 1 \\
\hline Portugal & 3 & Cameroon & 2 & Ivory Coast & 3 & Tunisia & 2 \\
\hline Romania & 2 & Canada & 1 & Japan & 1 & Uruguay & 1 \\
\hline Russia & 1 & China & 1 & Macedonia & 2 & USA & 1 \\
\hline Sweden & 2 & Denmark & 7 & Mexico & 2 & & \\
\hline Turkey & 3 & & & & & & \\
\hline
\end{tabular}

\begin{tabular}{lcc}
\hline All Euro 2008: 148 & All non-Euro 2008: 77 & Total: 225 \\
\hline Notes: The sample excludes goalkeepers, players of Austrian or Swiss nationality, or players for whom we have observa-
\end{tabular}
tions in one season only or only either after or before the official Euro 2008 qualification date.

Table 1 lists the players' nationalities. The treatment group euro consists of the 148 players whose nations participated in the Euro 2008. The 77 remaining players are in the control group non-euro, which includes non-Europeans whose national teams are excluded from the Euro Cup by UEFA rules and Europeans whose teams did not qualify. About half the players are German, the others come from all over the world.

\footnotetext{
${ }^{22}$ We used ESPNsoccernet.com, FIFA.com, Kicker.de, Worldfootball.net, footballdatabase.eu, and the sites of national soccer associations.

${ }^{23}$ An observation in our data is conditional on a player's availability. That is, players with suspensions or sickness are treated as having a missing observation on a given game day. The underlying causes of such absences are less in the players' control than our performance measures and we assume they are missing at random.
} 


\subsubsection{Performance measurement}

The Bundesliga data contain a variety of individual outputs that are meaningful measures of performance: passes received, ball contacts, shots on goal, goals, and duels won. Passes received counts the number of passes a player receives from his teammates in a game. It is a good indicator of how active and fit a player is, and of his teammates' trust in his ability to make a valuable contribution. Ball contacts is a more aggregate measure of how involved a player is and also reflects a player's success in obtaining the ball. Goals is a natural performance measure because the ultimate objective in soccer is to score goals (and prevent goals by the opponent); however, it is not unusual for games to end without any goals and this measure has a highly skewed distribution. We therefore use shots on goal, which includes both actual goals and failed goal attempts, as another key measure of offensive performance. A duel is a situation in which two players fight for the ball in direct confrontation and counts as won if the player or one of his teammates end up obtaining the ball. Duels won measures physical fitness and dedication.

The data also include detailed information on player substitutions, which allows us to determine whether a player was a "starter" (i.e., on the field at the start of the game) and to compute the number of minutes each player spent on the field ${ }^{24}$ It makes sense to view both the number of minutes played and whether a player was a starter as additional performance measures, because club coach's substitution decisions are influenced by player's performances on the field and during training ${ }^{25}$ Finally, the data report fouls and yellow/red cards that soccer referees use to indicate and punish fouls. We will use these to test whether the Euro 2008 career prospect had any effect on destructive effort or sabotage aimed at players of the opponent team.

In addition to the objective measures listed so far, we collected the grades that the soccer magazines Kicker and Sportal assign to players after each game. Grades have the advantage of providing an overall assessment of a player's multi-dimensional performance; however, they are subjective judgements and may hence be biased. We use the mean of the grades from two different magazines as we expect that averaging mitigates some of these biases. Grades are expressed as numbers between 0 (insufficient) and 5 (excellent) ${ }^{26}$

\footnotetext{
${ }^{24}$ Coaches are allowed to make at most three substitutions per game, and typically make use of this possibility at least twice. Approximately $80 \%$ of substitutions take place in the last third of a game.

${ }^{25}$ We will also use the data on minutes played to test whether the Euro 2008 career prospect had an effect on performance per minute for those players with field appearances.

${ }^{26}$ When a player does not receive a grade for a game because he spent either the entire time in reserve or fewer than 30 minutes (the magazines' cut-off level) on the field, we assign an "insufficient" (0) to the player for this game. A soccer game lasts 90 minutes, plus potentially a few minutes of additional time
} 
For ease of exposition, we will also use a performance index equal to the sum of the individual performance measures passes received, ball contacts, shots on goal, goals, duels won, and mean grade, standardized by their means and standard deviations. ${ }^{27}$ Table 2 reports the correlations between the various output measures. All correlations are positive, but some are weak, suggesting that different output measures capture different dimensions of performance.

Table 2: Correlations between performance measures

\begin{tabular}{|c|c|c|c|c|c|c|c|c|c|c|c|c|}
\hline Variables & Index & $\begin{array}{l}\text { Passes } \\
\text { received }\end{array}$ & $\begin{array}{c}\text { Ball } \\
\text { contacts }\end{array}$ & $\begin{array}{l}\text { Shots } \\
\text { on goal }\end{array}$ & Goals & $\begin{array}{l}\text { Duels } \\
\text { won }\end{array}$ & Grades & $\begin{array}{l}\text { Minutes } \\
\text { played }\end{array}$ & Starter & $\begin{array}{c}\text { Index } \\
\text { per minute }\end{array}$ & $\begin{array}{c}\text { Yellow/Red } \\
\text { Card }\end{array}$ & $\begin{array}{c}\text { Fouls } \\
\text { committed }\end{array}$ \\
\hline Passes received & .81 & 1.00 & & & & & & & & & & \\
\hline Ball contacts & .84 & .91 & 1.00 & & & & & & & & & \\
\hline Shots on goal & .63 & .35 & .29 & 1.00 & & & & & & & & \\
\hline Goals & .47 & .10 & .07 & .40 & 1.00 & & & & & & & \\
\hline Duels won & .78 & .60 & .74 & .32 & .12 & 1.00 & & & & & & \\
\hline Grades & .84 & .58 & .66 & .42 & .39 & .63 & 1.00 & & & & & \\
\hline Minutes played & .83 & .72 & .85 & .36 & .14 & .79 & .75 & 1.00 & & & & \\
\hline Starter & .75 & .67 & .78 & .32 & .12 & .72 & .67 & .92 & 1.00 & & & \\
\hline Index per minute & .73 & .57 & .56 & .50 & .40 & .51 & .64 & .46 & .38 & 1.00 & & \\
\hline Yellow/Red card & .13 & .11 & .16 & .04 & .01 & .16 & .11 & .18 & .18 & .09 & 1.00 & \\
\hline Fouls committed & .38 & .30 & .36 & .17 & .07 & .43 & .34 & .45 & .43 & .23 & .33 & 1.00 \\
\hline Fouls suffered & .48 & .38 & .41 & .25 & .10 & .57 & .37 & .44 & .41 & .33 & .12 & .28 \\
\hline
\end{tabular}

Notes: The sample excludes goalkeepers, players of Austrian or Swiss nationality, or players for whom we have observations in one season only or only either after or before the official Euro 2008 qualification date.

Table 3 presents summary statistics for players in the control (non-euro) and treatment (euro) groups. All statistics refer to Bundesliga club games. As a first observation, it should be noted that in the pre-qualification period non-euro players performed slightly better and spent more time on the field than euro players, whereas these rankings were reversed in the post-qualification period.

to make up for delays.

${ }^{27}$ To facilitate the interpretation of results, we standardize the sum of the six (standardized) performance measures once more so that the performance index also has a standard deviation of 1 . 
Table 3: Summary statistics

\begin{tabular}{|c|c|c|c|c|}
\hline \multirow[b]{2}{*}{$N=11316$} & \multicolumn{2}{|c|}{ euro } & \multicolumn{2}{|c|}{ non-euro } \\
\hline & Mean & S.d. & Mean & S.d. \\
\hline \multicolumn{5}{|l|}{ Pre-qualification } \\
\hline Defense (dummy) & .35 & .48 & .39 & .49 \\
\hline Midfield (dummy) & .47 & .50 & .39 & .49 \\
\hline Forward (dummy) & .19 & .39 & .21 & .41 \\
\hline Game Starter & .83 & .37 & .69 & .47 \\
\hline Minutes played & 64.94 & 35.30 & 67.12 & 33.78 \\
\hline Performance index & 5.80 & 5.13 & 6.17 & 5.31 \\
\hline Passes received & 19.80 & 14.72 & 20.98 & 14.96 \\
\hline Ball contacts & 40.07 & 26.07 & 42.44 & 26.23 \\
\hline Shots on goal & 1.06 & 1.42 & 1.13 & 1.42 \\
\hline Goals & .10 & .33 & .11 & .35 \\
\hline Duels won & 8.76 & 6.17 & 9.35 & 6.07 \\
\hline Journalist grade & 1.90 & 1.20 & 1.99 & 1.78 \\
\hline Yellow/red card & .13 & .33 & .13 & .34 \\
\hline Fouls committed & 1.31 & 1.37 & 1.32 & 1.43 \\
\hline Fouls suffered & 1.40 & 1.44 & 1.10 & 1.35 \\
\hline \multicolumn{5}{|l|}{ Post-qualification } \\
\hline Defense (dummy) & .37 & .48 & .39 & .49 \\
\hline Midfield (dummy) & .47 & .50 & .43 & .50 \\
\hline Forward (dummy) & .16 & .37 & .18 & .39 \\
\hline Game Starter & .85 & .35 & .56 & .50 \\
\hline Minutes played & 62.22 & 36.74 & 61.09 & 36.89 \\
\hline Performance index & 5.55 & 5.23 & 5.40 & 5.05 \\
\hline Passes received & 19.68 & 15.46 & 20.11 & 16.13 \\
\hline Ball contacts & 39.19 & 26.95 & 40.33 & 28.45 \\
\hline Shots on goal & .97 & 1.37 & .94 & 1.33 \\
\hline Goals & .10 & .34 & .08 & .31 \\
\hline Duels won & 8.32 & 6.10 & 8.37 & 6.10 \\
\hline Journalist grade & 1.80 & 1.24 & 1.78 & 1.25 \\
\hline Yellow/red card & .13 & .33 & .10 & .30 \\
\hline Fouls committed & 1.16 & 1.20 & 1.15 & 1.36 \\
\hline Fouls suffered & 1.27 & 1.26 & 1.01 & 1.29 \\
\hline Age & 26.81 & 4.08 & 28.75 & 3.38 \\
\hline
\end{tabular}

Notes: 148 euro players $(N=7496)$ and 77 non-euro players $(N=3820)$. Player age is measured on 17 May 2008, the last game day preceding the Euro 2008. The sample excludes goalkeepers, players of Austrian or Swiss nationality, or players for whom we have observations in only one season or only either after or before the official Euro 2008 qualification date. Pre-qualification designates the time period prior to the official Euro 2008 qualification date. 


\section{Empirical analysis}

\subsection{Measurement of heterogeneous national team selection chances}

Our theory predicts that the Euro Cup career prospect affects the effort incentives and hence performances of players who have a chance to make it into a Euro Cup national team. The predicted effect is positive for players with intermediate chances whose priority is to impress the national team coach, but small or even negative for players with very good chances, because their priority is to avoid fatigue and injuries prior to the Cup.

To allow for such heterogeneous effects in the subsequent empirical analyses, we use data on players' national team selections prior to the Euro 2008 qualification decisions. Because past national team selections are based on national team coaches' perceptions of players' skills, one would expect players with many (especially recent) past selections to have greater future chances of being selected for the Euro 2008 than players with few or no past national team selections. For each player $i$, we therefore compute

$$
\text { selection } \text { ratio }_{i}=\frac{\text { number of } i \text { 's field appearances in national team games }}{\text { total number of games played by } i \text { 's national team }}
$$

in the 30 months leading up to the Euro 2008 qualification decisions 28 Since recent selections are likely to be more informative about a player's chance of a Euro 2008 selection than more distant selections, we also divide the 30 months prior to the Euro 2008 qualification decisions into five 6-months windows and compute selection ratio for each 29

Table 4 shows the results of logit regressions of actual Euro 2008 team selections on selection ratio 30 The estimates confirm that Euro 2008 team selections were highly correlated with past selections: the model in column (1) with selection ratio over the entire 30 months as the only regressor predicts $93 \%$ of selections correctly. Column (2) shows that recent selections are more predictive than more distant selections. Only the two most recent selection ratio variables have significant estimated coefficients, and the selection

\footnotetext{
${ }^{28}$ National team games include friendly games, qualification games for international tournaments, and games in other tournaments. Only actual field appearances are used to compute selection ratio because we were unable to obtain the full list of reserve players for some national team games.

${ }^{29}$ As mentioned earlier, some nations already qualified for the Euro 2008 a couple of weeks prior to the official qualification date on Nov. 21, 2007; we use these de facto qualification dates as the end dates for computing selection ratio for players in the euro group. For players in the control group, national team games until the official qualification date are included. None of our results would change if we used the official qualification date as the cutoff date for all players.

${ }^{30}$ Only euro group players were included in these regressions, because players in the control group could not participate in the Euro 2008, so the dependent variable is meaningless for them.
} 
ratio for the 6 months closest to the qualification decisions has the highest estimated coefficient.

Table 4: Logit regression of Euro 2008 national team selection

\begin{tabular}{|c|c|c|}
\hline & \multicolumn{2}{|c|}{$\begin{array}{l}\text { Dependent variable: } \\
\text { Euro } 2008 \text { selection }\end{array}$} \\
\hline & (1) & $(2)$ \\
\hline Selection ratio (0-30 months before) & $(.088)^{.56 * *}$ & \\
\hline Selection ratio (0-6 months before) & & $\underbrace{.21^{* * *}}$ \\
\hline Selection ratio (6-12 months before) & & $(.055)$ \\
\hline Selection ratio (12-18 months before) & & $\begin{array}{r}.13 \\
(.121)\end{array}$ \\
\hline Selection ratio (18-24 months before) & & $\begin{array}{l}-.01 \\
(.075)\end{array}$ \\
\hline Selection ratio (24-30 months before) & & $\begin{array}{r}.02 \\
(.090)\end{array}$ \\
\hline Constant & $\begin{array}{l}-.23 * * * \\
(.035)\end{array}$ & $\underbrace{.23 * * *}_{(.035)}$ \\
\hline $\mathrm{N}$ & 148 & 148 \\
\hline Percent correctly predicted & .93 & .95 \\
\hline Pseudo $\mathrm{R}^{2}$ & .60 & .75 \\
\hline Log-Likelihood & 31.99 & 19.83 \\
\hline
\end{tabular}

For subsequent analyses, we will use fitted values from the logit regression in column (2) of Table 4 to rank players based on their national team selection chances. Table 12 in the Appendix reports the predicted selection chances (henceforth "selectchance") based on this regression along with actual Euro 2008 selections for players in the euro group. With the exception of one player (Bernd Schneider) who suffered a severe injury just before the championship, all euro group players with selectchance greater than .9 indeed played in the Euro 2008. Out of the 5 euro group players with selectchance between 8 and .9, 4 (or 80\%) were selected for Euro 2008, whereas only $44 \%$ of the 16 players with selectchance between .1 and .8 participated in the Cup. Finally, only 2 out of the more than 100 players with very low predicted chances (selectchance $<.1$ ) were selected for the Euro 2008. In our sample, selectchance $>0$ for 56 out of the 148 players in the treatment group, and for 62 of the 77 players in the control group. Conditional on being positive, the mean value is .59 in the treatment group and .56 in the control group. 


\subsection{Performance impact of the Euro 2008 career prospect}

\subsubsection{Trends in the raw data}

Since theory predicts that the impact of the Euro 2008 career prospect depends on a player's selection chance, as a first step we divide players into three subsamples according to selectchance. The cutoffs are based on tertiles in the sample of all players with selectchance $>0$, which results in selectchance cutoff values of .29 and .91.31

Table 13 in the Appendix shows summary statistics for the three selectchance subsamples. Post-qualification we observe a performance increase (decrease) of treatment group players relative to control group players in the medium (high) selectchance subsample.

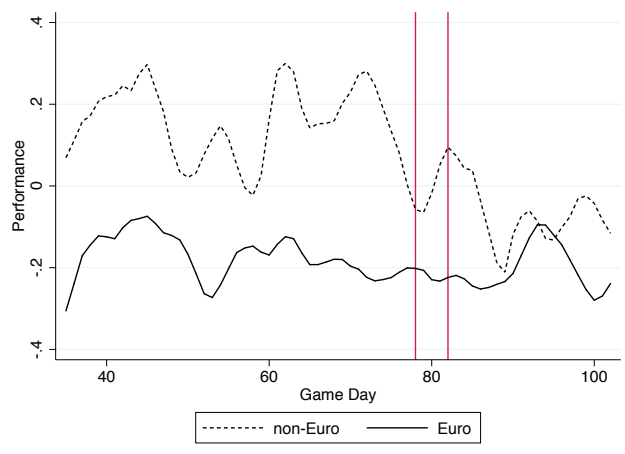

(i) Low selectchance

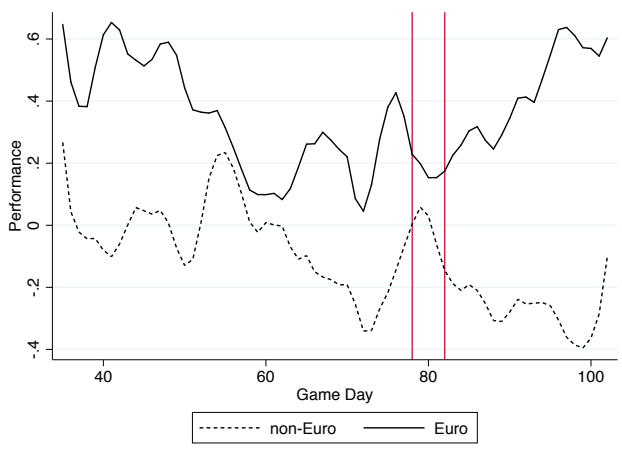

(ii) Medium selectchance

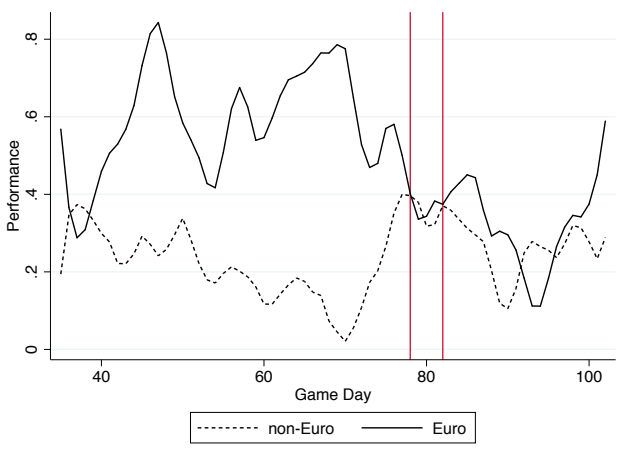

(iii) High selectchance

Figure 3: Player performance over time - smoothed (lowess with bandwidth .1)

Figure 3 plots the performance index over time in each selectchance subsample. The two vertical lines indicate the time window of (de facto) Euro 2008 qualification decisions ${ }^{32}$ For players with medium selectchance values, the treatment and control groups

\footnotetext{
${ }^{31}$ Percentiles are determined using only players with selectchance $>0$ because past national team selections do not allow us to rank players with selectchance $=0$ in terms of their likelihood of making their national team. Online Appendix B contains results for a division of the sample into four strata based on quartiles.

${ }^{32}$ As mentioned, some countries qualified for the Euro 2008 prior to the official qualification date.
} 
evolve similarly in the pre-qualification period, but there is a clear divergence post qualification, with treated players improving relative to control group players. For players with high selectchance values, on the other hand, we observe a decrease in the performance of the treatment group post qualification. The figures for players with medium and high selectchance values provide a first indication that players' performances indeed responded to the career prospect of being selected to play in the Euro 2008 and that players differed in their responses depending on their selection chance.

\subsubsection{Basic regression analysis}

To control for potential confounding factors that may drive the trends in the raw data, we estimate, for each of the three selectchance subsamples defined in the last subsection, the following regression equation that includes player fixed effects and several time-varying control variables:

$$
Y_{i t}=\delta_{0} \text { euro }_{i} \times \text { post }_{i t}+\gamma_{i}+\alpha_{t}+X_{i t}^{\prime} \beta+\varepsilon_{i t}
$$

where $Y_{i t}$ is player $i$ 's performance on game day $t$. The treatment interaction term post $_{i t} \times$ euro $_{i}$ equals 1 if and only if player $i$ 's nation is qualified for the Euro 2008 at time $t$ The coefficient of primary interest will be $\delta_{0}{ }^{34}$ The player fixed effects $\gamma_{i}$ pick up (timeinvariant) skill differences between players, and the game day fixed effects $\alpha_{t}$ control for changes in playing conditions over time that affect all clubs. $X_{i t}$ includes dummies that indicate the club the player currently works for ${ }^{35}$ and dummies that indicate the opponent team $i$ 's club faces on day $t$. Moreover, $X_{i t}$ includes field position dummies, as players sometimes occupy different positions (forward, midfield or defense) in different games. Finally, $X_{i t}$ includes a homegame $i t$ dummy indicating whether $i$ 's current club plays in

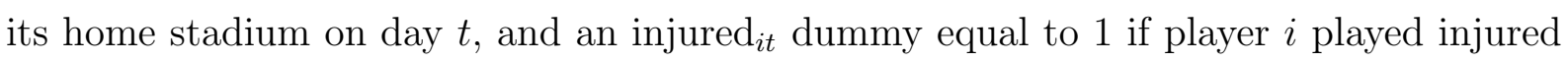
or weakened from a past injury on game day $t 36$

Table5 5 reports regression results for each of the three selectchance subsamples with the

\footnotetext{
${ }^{33}$ For treatment group players $\left(\operatorname{euro}_{i}=1\right)$, post $i t$ equals 1 from the day of $i$ 's nation's de facto qualification for the Euro 2008. For control group players $\left(\operatorname{euro}_{i}=0\right)$, post $i t$ equals 1 from the official Euro 2008 qualification date (Nov. 21, 2007) onwards. None of the results would change if for all $i$ we set post ${ }_{i t}$ equal to a player-invariant dummy post ${ }_{t}$ indicating the time period after the official qualification date.

${ }^{34}$ To eliminate bias due to incorrect weighting in the fixed effect estimate (Gibbons et al. 2014), we estimate $\delta_{0}$ by interacting player dummies with the treatment term to obtain $\delta_{0 i}$ and, in a second step, computing the sample-weighted average treatment effect following Wooldridge (2005), $\delta_{0}=\sum_{i} \frac{N_{i}}{N} \delta_{0 i}$.

${ }^{35}$ Several players moved between Bundesliga clubs in the sample period.

${ }^{36}$ It should be noted that our Bundesliga dataset contains only observations for players who were either on the reserve bench or on the field. However, there will be missing observations for a player who misses games altogether because of an injury.
} 
Table 5: Treatment effects in each selectchance subsample

\begin{tabular}{|c|c|c|c|c|}
\hline & \multicolumn{4}{|c|}{ Dependent variable: performance index } \\
\hline & $(1)$ & $(2)$ & (3) & $(4)$ \\
\hline \multicolumn{5}{|c|}{ Low selectchance $($ no. of observations $=7124)$} \\
\hline euro $\times$ post & $\begin{array}{r}.45 \\
(.485)\end{array}$ & $\begin{array}{r}.48 \\
(.474)\end{array}$ & $\begin{array}{r}.34 \\
(.360)\end{array}$ & $\begin{array}{r}.30 \\
(.367)\end{array}$ \\
\hline euro & $\begin{array}{l}-1.28^{* *} \\
(.523)\end{array}$ & $\begin{array}{l}-.92^{*} \\
(.464)\end{array}$ & & \\
\hline post & $\begin{array}{l}-.59 \\
(.409)\end{array}$ & $\begin{array}{l}-.49 \\
(.409)\end{array}$ & & \\
\hline injured & & $\begin{array}{l}-.60^{*} \\
(.324)\end{array}$ & & $\begin{array}{l}-1.15^{* * *} \\
(.308)\end{array}$ \\
\hline age & & $\begin{array}{l}1.22 \\
(.507)\end{array}$ & & \\
\hline age $^{2}$ & & $\begin{array}{l}-.02^{* *} \\
(.009)\end{array}$ & & \\
\hline homegame & & $\underbrace{.74^{* * *}}_{(.103)}$ & & $\underbrace{.71 * * *}_{(.104)}$ \\
\hline \multicolumn{5}{|c|}{ Medium selectchance ( no. of observations $=2067)$} \\
\hline euro $\times$ post & $\begin{array}{c}.34^{*} \\
(.643)\end{array}$ & $\begin{array}{c}.33^{*} \\
(.622)\end{array}$ &.$_{(.102)}^{.27 * *}$ &.$_{(.102)}^{.27^{* *}}$ \\
\hline euro & $\begin{array}{l}.39 * * * \\
(.732)\end{array}$ & $\begin{array}{l}.41^{* *} \\
(.109)\end{array}$ & & \\
\hline post & $\begin{array}{l}-.24 * * \\
(.441)\end{array}$ & $\begin{array}{l}-.24^{* *} \\
(.378)\end{array}$ & & \\
\hline injured & & $\begin{array}{l}-.15 \\
(.458)\end{array}$ & & $\begin{array}{l}-.15 \\
(.092)\end{array}$ \\
\hline age & & $\begin{array}{r}-.21 \\
(3.025)\end{array}$ & & \\
\hline age $^{2}$ & & $\begin{array}{l}.004 \\
(.053)\end{array}$ & & \\
\hline homegame & & $\frac{.20 * * *}{(.195)}$ & & ${ }_{(.031)}^{.20^{* * *}}$ \\
\hline \multicolumn{5}{|c|}{ High selectchance ( no. of observations $=2125$ ) } \\
\hline euro $\times$ post & $\begin{array}{l}-.30^{* *} \\
(.125)\end{array}$ & $\begin{array}{l}-.31^{* *} \\
(.125)^{2}\end{array}$ & $\begin{array}{l}-.39^{* * *} \\
(.088)^{2}\end{array}$ & $\begin{array}{l}-.39 * * * \\
(.089)\end{array}$ \\
\hline euro & $\underbrace{.34 * *}_{(.160)}$ & $\begin{array}{c}.29^{*} \\
(.151)\end{array}$ & & \\
\hline post & $\begin{array}{r}.06 \\
(.083)\end{array}$ & $\begin{array}{r}.08 \\
(.085)\end{array}$ & & \\
\hline injured & & $\begin{array}{l}-.20 * * \\
(.097)\end{array}$ & & $\begin{array}{l}-.32^{* * *} \\
(.083)\end{array}$ \\
\hline age & & $\begin{array}{l}-.19 \\
(.458)\end{array}$ & & \\
\hline age $^{2}$ & & $\begin{array}{l}.003 \\
.008)\end{array}$ & & \\
\hline homegame & & $\left(^{.028)}{ }^{.12 * *}\right.$ & & $\left(_{(.027)}^{.12 * * *}\right.$ \\
\hline Player FE & No & No & Yes & Yes \\
\hline Game day FE & No & No & Yes & Yes \\
\hline Field position dummies & No & Yes & No & Yes \\
\hline Club dummies & No & Yes & No & Yes \\
\hline Opponent dummies & No & Yes & No & Yes \\
\hline
\end{tabular}

Notes: Linear regression results with robust standard errors clustered at the player level between parentheses. The subsamples Low, Medium, and High selectchance are based on tertiles of selectchance for players with at least one national team selection, with selectchance cutoffs .29 and .91.

***Significant at the 1 percent level.

** Significant at the 5 percent level.

*Significant at the 10 percent level. 
performance index as the dependent variable. The first two columns report estimates of OLS regressions without player and game day fixed effects, whereas the last two columns report the results of regressions that include those fixed effects ${ }^{37}$ Column 4 corresponds to our main specification in equation (3). In all regressions, standard errors are robust and clustered at the individual player level to take into account serial correlation. The resulting estimator of the variance-covariance matrix is consistent as the number of players in our data is large (see Bertrand et al. 2004).

For players with low selectchance values, the treatment effect is not estimated significantly different from zero in any of the specifications. For players with medium selectchance values, the estimated treatment effect is positive and significant in all specifications and equal to about .3 standard deviations in the full specification that includes all fixed effects and covariates (column 4). For players with high selectchance values, the estimated treatment effect is negative and significant in all specifications and equals about -.46 standard deviations in the full specification ${ }^{38}$ The control variables have the expected signs. The effect of homegame is positive and highly significant in all regressions, and playing injured has negative effects.

Inclusion of player and game day fixed effects somewhat decreases the estimated positive treatment effect for players with medium selectchance values, and amplifies the estimated negative treatment effect for players with high selectchance values. As will be discussed in more detail in Section 6.2, the estimates without player fixed effects may be biased upwards because for European players who participated in the qualification games for the Euro 2008 selection into the treatment group may not be completely random. Player fixed effects alleviate such concerns by controlling for (time-invariant) skill differences between individual players.

\subsubsection{Non-linear interaction between the treatment and selectchance}

To investigate the relation between selectchance and the impact of the Euro Cup career prospect further and without imposing somewhat arbitrary cutoffs between groups of players with different selection chances, we estimate the following linear regression specification including interaction terms between the treatment indicator euro $_{i} \times$ post $_{i t}$ and a

\footnotetext{
${ }^{37}$ The specification in (3) with player fixed effects relies on the strict exogeneity assumption, $E\left(\varepsilon_{i t} \mid X_{i 1}, \ldots, X_{i T}, \gamma_{i}\right)=0$, that rules out correlation between the disturbance and explanatory variables for all $t$. We therefore also report pooled OLS estimates, which only require contemporaneous exogeneity.

${ }^{38}$ To obtain a more tangible picture of the magnitudes of the effects, we will analyze separate performance measures (rather than an index) in Section 5.3.
} 
quadratic function of selectchance:

$$
\begin{aligned}
Y_{i t}= & \delta_{1} \text { euro }_{i} \times \text { post }_{i t}+\delta_{2} \text { euro }_{i} \times \text { post }_{i t} \times \text { selectchance }_{i}+\delta_{3} \text { euro }_{i} \times \text { post }_{i t} \times \text { selectchance }_{i}^{2} \\
& +\pi_{1} \text { post }_{i t} \times \text { selectchance }_{i}+\pi_{2} \text { post }_{i t} \times \text { selectchance }_{i}^{2} \\
& +\gamma_{i}+\alpha_{t}+X_{i t}^{\prime} \beta+\varepsilon_{i t}
\end{aligned}
$$

The parameters of primary interest are $\delta_{1}, \delta_{2}$, and $\delta_{3}$. In particular, the relation between selectchance and the strength of the treatment effect is qualitatively similar to the theoretical prediction in Figure 1 if $0=\delta_{1}<\delta_{2}<-\delta_{3}$. Under these conditions, the treatment

effect reaches its maximum at selectchance equal to $-\frac{\delta_{2}}{2 \delta_{3}} \in\left(0, \frac{1}{2}\right)$ and is positive if and only if selectchance lies below $-\frac{\delta_{2}}{\delta_{3}} \in(0,1]$.

As shown in Table 14 in the Appendix, the estimates of $\delta_{2}$ and $\delta_{3}$ have the expected signs and relative magnitudes and are both significant at the $1 \%$ level. The maximum treatment effect occurs at selectchance $\approx .45$ and the selectchance threshold above which the treatment effect is negative equals .89. The latter is consistent with our earlier observation that all euro group players with selectchance greater than .9 who did not suffer an injury indeed played in the Euro 2008.

\subsubsection{Player-specific treatment effects}

A shortcoming of the regression approach with non-linear selectchance interactions in the previous subsection is that it imposes a quadratic functional form. We therefore use the following two-step approach to complement the previous analyses. First, we estimate player-specific treatment effects by running the following linear fixed effects regression using the full sample:

$$
Y_{i t}=\delta_{0 i} \operatorname{euro}_{i} \times \operatorname{post}_{i t}+\gamma_{i}+\alpha_{t}+X_{i t}^{\prime} \beta+\varepsilon_{i t}
$$

Second, we nonparametrically estimate the relation between the estimated player-specific treatment effects $\left(\delta_{0 i}\right)$ and players' selectchance values. This approach allows us to investigate the full relation between estimated treatment effects and selectchance without imposing any functional form assumption.

Figure 4 shows smoothed curves computed using local polynomial regression of the 


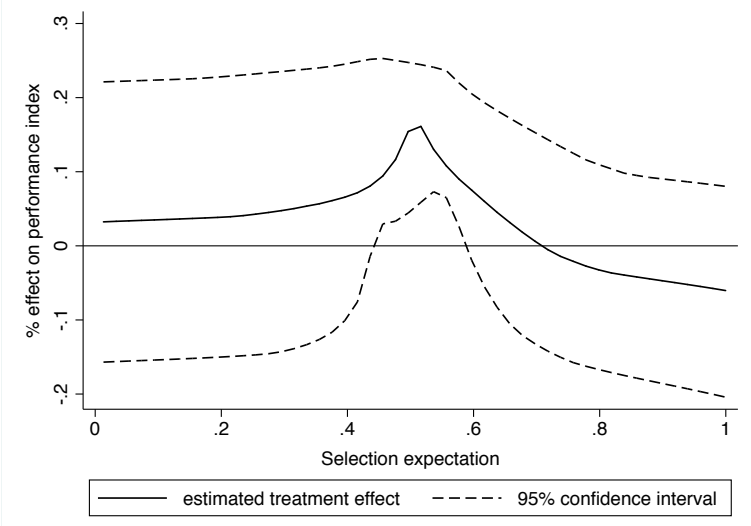

(i) Local mean smoothing

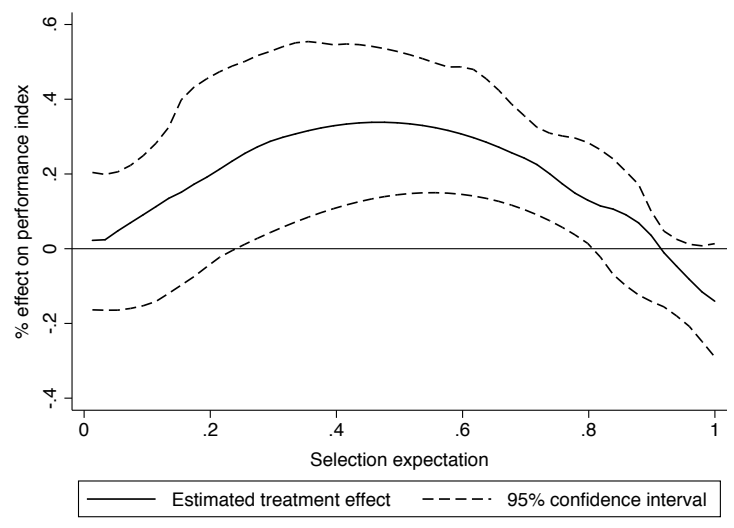

(ii) Local cubic regression

Figure 4: Treatment effects and selectchance

estimated player-specific treatment effects as a function of selectchance ${ }^{39}$ The dashed lines represent the smoothed player-specific 95\% confidence interval bounds. Consistent with our regression results so far, we observe that the estimated individual treatment effects are close to zero and insignificant for players with low values of selectchance, positive for players with intermediate values of selectchance, and negative for players with high values of selectchance 40 The results hence again confirm our prediction that the Euro Cup career prospect had a positive impact on the performances of players with intermediate chances of making their national team and a negative impact on the performances of players with very good chances of making their national team.

\subsection{Different dimensions of performance}

The results so far provide compelling evidence that the Euro 2008 career prospect affected the performances of players with intermediate or high chances of being selected for their national team, where performance was measured by an index comprised of passes received, ball contacts, shots on goal, goals, duels won, and grades assigned by sports magazines. In this section, we investigate the effects of the Euro 2008 career prospect on each of these measures individually as well as on several additional outputs.

\footnotetext{
${ }^{39}$ More specifically, smoothing is achieved by local mean smoothing and local cubic regression with a rule of thumb bandwidth selection.

${ }^{40}$ Note that, unlike in the previous regressions based on specifications $(3)$ and $(4)$, treated players are no longer compared to control group players with similar values of selectchance here. Instead, all treated players are assigned the same control group consisting of all non-euro players. In spite of this difference and the added functional flexibility, the (qualitative and quantitative) insights remain very similar.
} 


\subsubsection{Productive effort}

Columns one through six in Table 6 show results of the full regression specification in (3) for each of the individual measures in the performance index as the dependent variable, where the three subsamples are based on selectchance as before. The results are largely consistent across performance measures. In the medium selectchance subsample, the estimated treatment effects are positive for all performance measures except for duels won (where the estimated coefficient is positive but insignificant) and goals.41 In the high selectchance subsample, the estimated treatment effects are negative and significant (mostly at the $1 \%$ level) for all six performance measures.

Columns seven to nine in Table 6 report results for three additional output measures: starter (i.e., whether the player was on the field at the start of the game), minutes played, and performance per minute. For starter and minutes played, we again find significant positive effects in the medium selectchance sample and significant negative effects in the high selectchance sample. To ensure that differences in minutes played are not the sole driver of our findings, we also run our main regression specification with the performance index divided by the number of minutes played as the dependent variable (including only observations with minutes played $>0$ ). As shown in the final column of Table 6 , our findings are robust: the estimated treatment effect is again positive in the medium selectchance sample and negative in the high selectchance sample.

Table 7 provides an overview of the estimated magnitudes of effects based on these regressions. The estimated effects are economically significant, ranging between $10 \%$ and $20 \%$ for most output measures. The effects are also remarkably similar across performance measures, including the grades that players receive from sports magazines.

Estimation of a quadratic relation between the effect of the Euro 2008 career prospect and selectchance, as specified in (4), also yields results consistent with our earlier findings for the performance index (see Table 8). For all output measures, the estimates of $\delta_{2}$ and $\delta_{3}$ have the expected signs and relative magnitudes and are both significant. For the majority of output measures, the maximum treatment effect occurs for players with selectchance values around .45 and the selectchance threshold above which the treatment

\footnotetext{
${ }^{41}$ Contrary to our predictions, we obtain a significant negative effect for goals. Our results with four subsample based on selectchance quartiles, reported in Online Appendix B, suggest that this finding may be driven by a negative effect on the performances of player with medium to high selections chances: with four subsamples, we find a significant positive effect on of the Euro 2008 career prospect players in the second quartile and significant negative effects on players in the third on fourth higher quartiles. It should also be noted, however, that goals is noisier than the other available performance measures.
} 
Table 6: Different performance measures as the dependent variable

\begin{tabular}{|c|c|c|c|c|c|c|c|c|c|}
\hline & $\begin{array}{l}\text { Passes } \\
\text { received }\end{array}$ & $\begin{array}{c}\text { Ball } \\
\text { contacts }\end{array}$ & $\begin{array}{l}\text { Shots } \\
\text { on goal }\end{array}$ & Goals & $\begin{array}{l}\text { Duels } \\
\text { won }\end{array}$ & Grades & Starter & $\begin{array}{l}\text { Minutes } \\
\text { played }\end{array}$ & $\begin{array}{c}\text { Index } \\
\text { per minute }\end{array}$ \\
\hline \multicolumn{10}{|c|}{ Low selectchance (no. of observations $=7124$, last column: 5946 ) } \\
\hline euro $\times$ post & $\begin{array}{r}1.42 \\
(1.183)\end{array}$ & $\begin{array}{r}2.54 \\
(2.293)\end{array}$ & $\begin{array}{r}.06 \\
(.105)\end{array}$ & $\begin{array}{r}.02 \\
(.015)\end{array}$ & $\begin{array}{l}1.05^{*} \\
(.558)\end{array}$ & $\begin{array}{r}.05 \\
(.099)\end{array}$ & $\begin{array}{l}.08^{*} \\
(.045)\end{array}$ & $\begin{array}{r}4.79 \\
(3.611)\end{array}$ & $\begin{array}{l}-.04 \\
(.045)\end{array}$ \\
\hline midfield & $\begin{array}{l}-5.34^{* * *} \\
(1.201)\end{array}$ & $\begin{array}{l}-16.91 * * * \\
(2.648)\end{array}$ & $\begin{array}{l}.24 * * * \\
(.078)\end{array}$ & $\begin{array}{l}.02 \\
(.013)\end{array}$ & $\begin{array}{l}-2.09 * * * \\
(.783)\end{array}$ & $\begin{array}{l}-.46^{* * *} \\
(.115)\end{array}$ & $\begin{array}{l}-.22 * * * \\
(.051)\end{array}$ & $\begin{array}{l}-19.79^{* * *} \\
(4.119)\end{array}$ & $\begin{array}{r}.02 \\
(.052)\end{array}$ \\
\hline forward & $\begin{array}{l}-6.94^{* * *} \\
(1.992)\end{array}$ & $\begin{array}{l}-20.39 * * * \\
(3.757)\end{array}$ &.$_{(.152)}^{.45^{* * *}}$ & ${ }_{(.025)}^{.06 * *}$ & $\begin{array}{l}-2.83^{* * *} \\
(.968)\end{array}$ & $\begin{array}{l}-.54^{* * *} \\
(.178)\end{array}$ & $\begin{array}{l}-.26^{* * *} \\
(.078)\end{array}$ & $\begin{array}{l}-24.22 * * * \\
(6.083)\end{array}$ & $\begin{array}{r}.09 \\
(.083)\end{array}$ \\
\hline injured & $\begin{array}{l}-2.75 * * * \\
(.732)\end{array}$ & $\begin{array}{l}-4.98 * * * \\
(1.404)\end{array}$ & $\begin{array}{l}-.26 * * * \\
(.075)^{*}\end{array}$ & $\begin{array}{r}-.03 \\
(.017)\end{array}$ & $\begin{array}{l}-1.12 * * * \\
(.377)\end{array}$ & $\begin{array}{l}-.24^{* * *} \\
(.078)^{2}\end{array}$ & $\begin{array}{l}-.11 * * * \\
(.029)\end{array}$ & $\begin{array}{l}-9.41 * * * \\
(2.097)\end{array}$ & $\begin{array}{l}.04 \\
(.051)\end{array}$ \\
\hline homegame & $\begin{array}{l}1.74^{* * *} \\
(.284)\end{array}$ & $\begin{array}{l}2.02 * * * \\
(.439)\end{array}$ & $\begin{array}{l}.20 * * * \\
(.026)\end{array}$ & ${ }^{.03^{* * *}}$ & ${ }_{(.118)}^{.24 * *}$ & ${ }_{(.023)}^{.13^{* * *}}$ & $\begin{array}{l}-.01^{*} \\
(.007)\end{array}$ & $\begin{array}{l}-.99 * \\
(.540)\end{array}$ & ${ }_{(.018)}^{.18^{* * *}}$ \\
\hline \multicolumn{10}{|c|}{ Medium selectchance ( no. of observations $=2067$, last column: 1835 ) } \\
\hline euro $\times$ post & $\begin{array}{l}4.70^{* * *} \\
(1.339)\end{array}$ & $\begin{array}{l}7.04^{* * *} \\
(2.162)\end{array}$ & $\frac{.46^{* * *}}{(.110)}$ & $\begin{array}{l}-.03^{*} \\
(.019)\end{array}$ & $\begin{array}{r}.83 \\
(.508)\end{array}$ & $\underset{(.126)}{.31 * *}$ & $\left(_{(.052)}^{.13^{* *}}\right.$ & $\begin{array}{l}8.91^{* *} \\
(4.034)\end{array}$ &.$_{(.054)}^{.18^{* * *}}$ \\
\hline midfield & $\begin{array}{r}-2.00 \\
(3.398)\end{array}$ & $\begin{array}{l}-10.87 \\
(6.688)\end{array}$ & $\underbrace{.36 * *}_{(.158)}$ & $\begin{array}{c}.04 \\
(.024)\end{array}$ & $\begin{array}{r}.07 \\
(1.076)\end{array}$ & $\begin{array}{l}-.01 \\
(.245)\end{array}$ & $\begin{array}{l}-.10 \\
(.084)\end{array}$ & $\begin{array}{l}-7.44 \\
(8.279)\end{array}$ & $\begin{array}{r}.07 \\
(.087)\end{array}$ \\
\hline forward & $\begin{array}{l}-4.87 \\
(3.831)\end{array}$ & $\begin{array}{l}-15.75^{* *} \\
(7.319)\end{array}$ & $\begin{array}{r}.39 \\
(.233)\end{array}$ & $\begin{array}{r}.06 \\
(.039)\end{array}$ & $\begin{array}{r}-.45 \\
(1.223)\end{array}$ & $\begin{array}{l}-.03 \\
(.293)\end{array}$ & $\begin{array}{l}-.19^{*} \\
(.106)\end{array}$ & $\begin{array}{l}-13.22 \\
(9.391)\end{array}$ & $\begin{array}{r}.21 \\
(.143)\end{array}$ \\
\hline injured & $\begin{array}{r}-.29 \\
(1.161)\end{array}$ & $\begin{array}{l}-3.31^{*} \\
(1.830)\end{array}$ & $\begin{array}{l}-.14 \\
(.165)\end{array}$ & $\begin{array}{l}-.06^{*} \\
(.033)\end{array}$ & $\begin{array}{l}-1.00^{* *} \\
(.454)\end{array}$ & $\begin{array}{l}-.11 \\
(.119)\end{array}$ & $\begin{array}{l}-.08^{*} \\
(.048)\end{array}$ & $\begin{array}{l}-5.48^{*} \\
(3.080)\end{array}$ & $\begin{array}{l}-.04 \\
(.083)\end{array}$ \\
\hline homegame & ${ }_{(.504)}^{2.08 * * *}$ & $\begin{array}{l}2.84^{* * *} \\
(.800)\end{array}$ & ${ }_{(.054)}^{.29 * * *}$ & ${ }_{(.013)}^{.04^{* * *}}$ & $\begin{array}{l}.63^{* * *} \\
(.193)\end{array}$ & $\underbrace{.24 * * *}_{(.039)}$ & $\begin{array}{l}.003 \\
(.014)\end{array}$ & $\begin{array}{l}1.60 \\
(.988)\end{array}$ & $\underset{(.042)}{.16 * * *}$ \\
\hline \multicolumn{10}{|c|}{ High selectchance ( no. of observations $=2125$, last column: 2016) } \\
\hline euro $\times$ post & $\begin{array}{l}-5.87 * * * \\
(1.338)\end{array}$ & $\begin{array}{l}-10.17 * * * \\
(2.407)\end{array}$ & $\begin{array}{l}-.24^{* * *} \\
(.080)\end{array}$ & $\begin{array}{l}-.04^{*} \\
(.020)\end{array}$ & $\begin{array}{l}-2.03^{* * *} \\
(.491)\end{array}$ & $\begin{array}{l}-.39^{* * *} \\
(.129)\end{array}$ & $\begin{array}{l}-.14^{* * *} \\
(.042)\end{array}$ & $\begin{array}{l}-11.07 * * * \\
(3.182)\end{array}$ & $\begin{array}{l}-.09 * * \\
(.039)\end{array}$ \\
\hline midfield & $\begin{array}{r}-4.31 \\
(2.733)\end{array}$ & $\begin{array}{l}-13.96^{* * *} \\
(4.769)\end{array}$ & $\underset{(.223)}{.40^{*}}$ & $\begin{array}{r}.02 \\
(.030)\end{array}$ & $\begin{array}{r}-.61 \\
(1.042)\end{array}$ & $\begin{array}{l}-.07 \\
(.151)\end{array}$ & $\begin{array}{l}-.06 \\
(.046)\end{array}$ & $\begin{array}{r}-5.40 \\
(3.557)\end{array}$ & $\begin{array}{l}-.10 \\
(.109)\end{array}$ \\
\hline forward & $\begin{array}{l}-9.06^{* * *} \\
(3.159)\end{array}$ & $\begin{array}{l}-23.52^{* * *} \\
(5.465)\end{array}$ & $\begin{array}{l}-.08 \\
(.283)\end{array}$ & $\left(_{(.063)}^{.16^{* *}}\right.$ & $\begin{array}{l}-1.61 \\
(1.327)\end{array}$ & $\begin{array}{l}-.16 \\
(.304)\end{array}$ & $\begin{array}{l}-.13^{*} \\
(.068)\end{array}$ & $\begin{array}{r}-9.09 \\
(5.561)\end{array}$ & $\begin{array}{l}-.25 \\
(.165)\end{array}$ \\
\hline injured & $\begin{array}{l}-3.86 * * * \\
(1.106)\end{array}$ & $\begin{array}{l}-5.60 * * * \\
(1.816)\end{array}$ & $\begin{array}{l}-.39 * * \\
(.155)\end{array}$ & $\begin{array}{l}-.09 * * \\
(.032)\end{array}$ & $\begin{array}{l}-1.38^{* *} \\
(.544)\end{array}$ & $\begin{array}{l}-.20^{* *} \\
(.093)\end{array}$ & $\begin{array}{l}-.10^{* * *} \\
(.032)\end{array}$ & $\begin{array}{l}-7.48^{* * * *} \\
(2.726)\end{array}$ & $\begin{array}{l}-.09^{*} \\
(.049)\end{array}$ \\
\hline homegame & $\begin{array}{l}1.75 * * * \\
(.565)\end{array}$ & ${ }_{(.787)}^{2.12^{* *}}$ & $\begin{array}{l}.26^{* * *} \\
(.053)\end{array}$ & $\begin{array}{l}-.003 \\
(.014)\end{array}$ & $\begin{array}{l}-. .01 \\
(.225)\end{array}$ & ${ }_{(.035)}^{.17^{* * *}}$ & $\begin{array}{l}.01 \\
(.011)\end{array}$ & $\begin{array}{l}-.22 \\
(.752)\end{array}$ & $\frac{.12^{* * *}}{(.021)}$ \\
\hline
\end{tabular}

Notes: The table reports linear fixed effects regression estimates. All specifications include player, gameday, club, and opponent fixed effects. Values between parentheses are robust standard errors clustered at the player level. The subsamples Low, Medium, and High selectchance are based on tertiles of selectchance for players with at least one national team selection, with selectchance cutoffs .29 and .91 .

*** Significant at the 1 percent level.

**Significant at the 5 percent level.

*Significant at the 10 percent level.

effect is negative is about .9. The only measure for which the thresholds are significantly lower is duels won (.39 and .77). A potential explanation could be that negative effects are more pronounced for duels because they carry a high risk of injury.

These results confirm that, across a wide range of performance measures, the Euro Cup career prospect had statistically and economically significant positive effects on the performances of players with intermediate chances of getting selected into their national team and statistically and economically significant negative impact on the performances of players with very good national team selection chances. 
Table 7: Magnitudes of estimated effects

\begin{tabular}{lrrrrrrrr}
\hline & $\begin{array}{c}\text { Passes } \\
\text { received }\end{array}$ & $\begin{array}{c}\text { Ball } \\
\text { contacts }\end{array}$ & $\begin{array}{c}\text { Shots } \\
\text { on goal }\end{array}$ & Goals & $\begin{array}{c}\text { Duels } \\
\text { won }\end{array}$ & Grades & $\begin{array}{r}\text { Starter } \\
\text { Minutes } \\
\text { played }\end{array}$ \\
\hline Medium selectchance & $19.3 \%$ & $15.8 \%$ & $31.8 \%$ & $-18.0 \%$ & $9.0 \%$ & $13.6 \%$ & $15.0 \%$ & $12.0 \%$ \\
High selectchance & $-21.2 \%$ & $-19.0 \%$ & $-14.6 \%$ & $-23.3 \%$ & $-18.2 \%$ & $-15.7 \%$ & $-15.7 \%$ & $-13.6 \%$ \\
\hline
\end{tabular}

Notes: The table reports effects in percentages of euro players' pre-treatment means in the respective subsamples, based on the regression results in Table 6 .

Table 8: Overview of estimated quadratic performance-selectchance relation

\begin{tabular}{|c|c|c|c|c|c|c|}
\hline & & $\begin{array}{l}\text { Performance } \\
\text { index }\end{array}$ & $\begin{array}{l}\text { Started } \\
\text { game }\end{array}$ & \multicolumn{2}{|c|}{$\begin{array}{l}\text { Minutes } \\
\text { played }\end{array}$} & $\begin{array}{c}\text { Index } \\
\text { per minute }\end{array}$ \\
\hline euro $\times \operatorname{post}\left(\delta_{1}\right)$ & \multicolumn{2}{|c|}{+} & + & + & \multicolumn{2}{|c|}{-} \\
\hline euro $\times$ post $\times$ selectchance $\left(\delta_{2}\right)$ & \multicolumn{2}{|c|}{$+* * *$} & $+* *$ & $+* *$ & \multicolumn{2}{|c|}{$+* * *$} \\
\hline euro $\times$ post $\times$ selectchance $^{2}\left(\delta_{3}\right)$ & \multicolumn{2}{|c|}{$-* * *$} & $-* * *$ & $-* * *$ & \multicolumn{2}{|c|}{$-* * *$} \\
\hline$\delta_{2}$ and $\delta_{3}$ jointly significant? & \multicolumn{2}{|c|}{ yes $* * *$} & yes** & yes** & \multicolumn{2}{|c|}{ yes ${ }^{* * *}$} \\
\hline$\delta_{2}<-\delta_{3}$ & \multicolumn{2}{|c|}{ yes** } & yes* & yes* & \multicolumn{2}{|c|}{ yes } \\
\hline max effect at selectchance & \multicolumn{2}{|c|}{$.45^{* * *}$} & $.45^{* * *}$ & $.44^{* * *}$ & \multicolumn{2}{|c|}{$.48 * * *$} \\
\hline zero effect at selectchance & \multicolumn{2}{|c|}{$.89^{* * *}$} & $.90 * * *$ & $.88^{* * *}$ & \multicolumn{2}{|c|}{$.96^{* * *}$} \\
\hline & $\begin{array}{l}\text { Passes } \\
\text { received }\end{array}$ & $\begin{array}{c}\text { Ball } \\
\text { contacts }\end{array}$ & $\begin{array}{l}\text { Shots } \\
\text { on goal }\end{array}$ & Goals & $\begin{array}{l}\text { Duels } \\
\text { won }\end{array}$ & Grades \\
\hline euro $\times$ post $\left(\delta_{1}\right)$ & - & - & + & - & + & - \\
\hline euro $\times$ post $\times$ selectchance $\left(\delta_{2}\right)$ & $+* * *$ & $+* * *$ & $+* * *$ & $+^{* *}$ & $+^{*}$ & $+* * *$ \\
\hline euro $\times$ post $\times$ selectchance $^{2}\left(\delta_{3}\right)$ & $-* * *$ & $-* * *$ & $-* * *$ & $-* *$ & $-* *$ & $-* * *$ \\
\hline$\delta_{2}$ and $\delta_{3}$ jointly significant? & yes $* * *$ & yes $* * *$ & yes $* * *$ & yes** & yes $* * *$ & yes*** \\
\hline$\delta_{2}<-\delta_{3}$ & yes** & yes $^{* *}$ & yes & yes & yes $* * *$ & yes* \\
\hline max effect at selectchance & $.45^{* * *}$ & $.44^{* * *}$ & $.47^{* * *}$ & $.46^{* * *}$ & $.39^{* * *}$ & $.46^{* * *}$ \\
\hline zero effect at selectchance & $.90^{* * *}$ & $.88^{* * *}$ & $.94^{* * *}$ & $.92^{* * *}$ & $.77^{* * *}$ & $.92 * * *$ \\
\hline
\end{tabular}

Notes: The table is based on the regression results in Tables 14 and 15 in the Appendix. The first three rows report sign and significance of the estimated coefficients of euro $\times$ post $\left(\delta_{1}\right)$, euro $\times$ post $\times$ selectchance $\left(\delta_{2}\right)$, and euro $\times$ post $\times$ selectchance ${ }^{2}\left(\delta_{3}\right)$. The fourth and fifth rows report the outcomes of Wald tests that $\delta_{2}=\delta_{3}=0$ and $\delta_{2}<-\delta_{3}$. The last two rows report the values of selectchance at which the treatment effect is maximal (selectchance $=-\frac{\delta_{2}}{2 \delta_{3}}$ ) and zero (selectchance $=-\frac{\delta_{2}}{\delta_{3}}$ ), as implied by these estimates. Their significance levels are computed using the delta method.

$* * *$ Significant at the 1 percent level.

**Significant at the 5 percent level.

*Significant at the 10 percent level. 


\subsubsection{Destructive effort}

In soccer, there are two types of effort: productive effort to improve one's own performance and "destructive effort" aimed at sabotaging players on the opponent team. Stronger (weaker) incentives to win games may increase (decrease) both types of effort (see Lazear 1989). To test whether the Euro 2008 career prospect affected destructive effort, we replicate our previous empirical analyses using fouls and yellow/red cards as dependent variables. Fouls are unfair acts such as kicking or tripping an opponent or using excessive force when tackling an opponent. More serious and/or persistent offenses lead to a yellow or red card being shown by the referee. ${ }^{42}$

Table 9 reports the results of regressions for three selectchance subsamples. We find no evidence that the Euro 2008 career prospect had an effect on how many cards a player receives. For fouls committed and fouls suffered, we find significant negative treatment effects in the high selectchance sample 43 However, we find no significant effects on fouls committed or suffered by players in the medium selectchance sample, and unexpected positive effects for players in the low selectchance sample ${ }^{44}$ With quadratic interactions between the Euro 2008 career prospect and selectchance, none of the regressors of interest are significant for fouls committed or suffered (see Table 16 in the Appendix). In summary, we find some evidence that the Euro 2008 career prospect had negative effects on fouls for players with high selection chances, but no consistent pattern of results to conclude that players with intermediate chances increased their destructive effort.

As mentioned earlier, related work by Garicano and Palacios-Huerta (2014) finds strong evidence that greater rewards to winning games increases destructive effort in soccer. Our analysis, on the other hand, shows no similar positive effect of the Euro 2008 career prospect. Two explanations come to mind. First, the Euro 2008 career prospect may not generate equally strong incentives to win club games as the rule change they consider, because national team coaches do not directly reward club team victories but make decisions based on their perceptions of individual abilities. Second, most of the

\footnotetext{
${ }^{42} \mathrm{~A}$ yellow card indicates that a player has been officially cautioned; a second caution in the same game leads to the player being sent off the field (with no substitute coming in to replace him). Red cards are reserved for the most serious offenses and lead to immediate dismissal. Since red cars are rare, we do not consider them as a separate output measure but instead pool them together with yellow cards.

${ }^{43}$ It should be noted that, unlike fouls committed, fouls suffered can be viewed as a measure of offensive performance, the idea being that stronger players are harder to stop for the opponent and may therefore suffer more fouls.

${ }^{44}$ In regressions with four subsamples based on selectchance quartiles, only the negative effect in the highest quartile remains significant for fouls suffered.
} 
Table 9: Destructive performance measures as dependent variable

\begin{tabular}{|c|c|c|c|}
\hline & $\begin{array}{c}\text { Red/Yellow } \\
\text { card }\end{array}$ & $\begin{array}{c}\text { Fouls } \\
\text { committed }\end{array}$ & $\begin{array}{c}\text { Fouls } \\
\text { suffered }\end{array}$ \\
\hline \multicolumn{4}{|c|}{ Low selectchance (no. of observations $=7124$ ) } \\
\hline euro $\times$ post & $\begin{array}{r}.02 \\
(.016)\end{array}$ & $\left(_{(.091)}^{.20 * *}\right.$ & $\begin{array}{c}.18^{*} \\
(.105)\end{array}$ \\
\hline midfield & $\begin{array}{l}-.01 \\
(.023)\end{array}$ & $\begin{array}{l}-.08 \\
(.142)\end{array}$ & $\begin{array}{l}-.13 \\
(.164)\end{array}$ \\
\hline forward & $\begin{array}{l}-.05^{*} \\
(.031)\end{array}$ & $\begin{array}{l}-.19 \\
(.169)\end{array}$ & $\begin{array}{l}-.12 \\
(.219)\end{array}$ \\
\hline injured & $\begin{array}{l}-.04^{*} \\
(.021)\end{array}$ & $\begin{array}{c}-.12 \\
(.081)\end{array}$ & $\begin{array}{c}-.04 \\
(.091)\end{array}$ \\
\hline homegame & $\begin{array}{l}-.02^{* * *} \\
(.007)\end{array}$ & $\begin{array}{l}-.10^{* * *} \\
(.027)\end{array}$ & $\begin{array}{l}-.04^{* *} \\
(.029)\end{array}$ \\
\hline \multicolumn{4}{|c|}{ Medium selectchance ( no. of observations $=2067$ ) } \\
\hline euro $\times$ post & $\begin{array}{r}.02 \\
(.091)\end{array}$ & $\begin{array}{l}-.10 \\
(.105)\end{array}$ & $\begin{array}{r}.09 \\
(.104)\end{array}$ \\
\hline midfield & $\begin{array}{r}.03 \\
(.025)\end{array}$ & $\begin{array}{r}.10 \\
(.204)\end{array}$ & $\begin{array}{r}.23 \\
(.170)\end{array}$ \\
\hline forward & $\begin{array}{c}-.04 \\
(.034)\end{array}$ & $\begin{array}{l}-.02 \\
(.273)\end{array}$ & $\begin{array}{r}.18 \\
(.198)\end{array}$ \\
\hline injured & $\begin{array}{l}.002 \\
(.036)\end{array}$ & $\begin{array}{l}-.11 \\
(.146)\end{array}$ & $\begin{array}{l}-.02 \\
(.130)\end{array}$ \\
\hline homegame & $\overline{(.015)}^{-.04^{* * *}}$ & $\overline{-.14}^{* *}$ & $(.061)^{*}$ \\
\hline \multicolumn{4}{|c|}{ High selectchance (no. of observations $=2125$ ) } \\
\hline euro $\times$ post & $\begin{array}{l}-.01 \\
(.026)\end{array}$ & $\begin{array}{l}-.30^{* * *} \\
(.102)\end{array}$ & $\begin{array}{l}-.30 * * * \\
(.089)\end{array}$ \\
\hline midfield & $\begin{array}{r}.05 \\
(.061)\end{array}$ & $\begin{array}{r}.36 \\
(.218)\end{array}$ & $\begin{array}{r}.21 \\
(.137)\end{array}$ \\
\hline forward & $\begin{array}{r}.04 \\
(.079)\end{array}$ & $\begin{array}{r}.28 \\
(.285)\end{array}$ & $\begin{array}{r}.30 \\
(.266)\end{array}$ \\
\hline injured & $\begin{array}{r}.01 \\
(.031)\end{array}$ & $\begin{array}{r}.14 \\
(.111)\end{array}$ & $\begin{array}{l}-.21 \\
(.134)\end{array}$ \\
\hline homegame & $\begin{array}{l}-.05^{* * *} \\
(.017)\end{array}$ & $\begin{array}{l}-.23^{* * *} \\
(.062)\end{array}$ & $\begin{array}{r}.07 \\
(.072)\end{array}$ \\
\hline
\end{tabular}

Notes: The table reports linear fixed effects regression estimates. All specifications include player, gameday, club, and opponent fixed effects. Values between parentheses are robust standard errors clustered at the player level. The subsamples Low, Medium, and High selectchance are based on tertiles of selectchance for players with at least one national team selection, with selectchance cutoffs .29 and .91 .

$* * *$ Significant at the 1 percent level.

**Significant at the 5 percent level.

* Significant at the 10 percent level. 
players on the opposing team in a club match are typically not competitors for spots on the same national team, which implies that often destructive effort in a club game does not sabotage a rival in the national team selection contest.

\subsubsection{Injuries}

Greater effort in soccer is usually associated with an increased probability of injury, especially as effort often goes hand in hand with taking more risks. One would therefore expect the Euro 2008 career prospect to have a positive effect on the incidence of injuries for players with intermediate national team selection chances. Conversely, one would expect a negative effect for players with high selection chances, who want to avoid fatigue and should shy away from actions that carry high injury risks.

To test directly whether the Euro 2008 career prospect affected the incidence of injuries, we define the variable "newinjury" that is equal to 1 on calendar day $t$ if the data report player $i$ as fit on calendar day $t-1$ but as injured on calendar day $t 55$ For each selectchance subsample, we then estimate the following regression equation:

$$
\text { newinjury }_{i t}=\delta_{0} \text { euro }_{i} \times \text { post }_{i t}+\gamma_{i}+\text { week }_{t}+\varepsilon_{i t},
$$

where $t$ is calendar day (rather than game day as in the previous analyses), post $\times$ euro indicates the Euro 2008 career prospect treatment, $\gamma_{i}$ are player fixed-effects, and week $k_{t}$ are time fixed-effects at the week level.

Table 10: Injuries

\begin{tabular}{llcc}
\hline & $\begin{array}{c}\text { Low } \\
\text { selectchance }\end{array}$ & $\begin{array}{c}\text { Medium } \\
\text { selectchance }\end{array}$ & $\begin{array}{c}\text { High } \\
\text { selectchance }\end{array}$ \\
\hline euro $\times$ post & .001 & $\left(.006^{* *}\right.$ & -.002 \\
no. of observations & $9702)$ & 25740 & $(.002)$ \\
\hline
\end{tabular}

Notes: The table reports linear fixed effects regression estimates. All specifications include player and calendar week fixed effects. Values between parentheses are robust standard errors clustered at the player level. The subsamples Low, Medium, and High selectchance are based on tertiles of selectchance for players with at least one national team selection, with selectchance cutoffs .29 and .91 . ${ }^{* *}$ Significant at the 5 percent level.

Table 10 reports the key results. We find a significant positive effect on the number of injuries suffered by players with intermediate selection chances, which is consistent with

\footnotetext{
${ }^{45}$ The data on injuries were provided by comunio.de, the largest German fantasy soccer platform (620,000 users in 2013). The website publishes the injury status of each player once a day in the morning.
} 
them exerting higher effort and taking greater risks to make it into the Euro 2008. For players with high selection chances, the estimated effect is large and negative $(-20 \%)$, as expected, although it fails to be statistically significant.

\section{Discussion and robustness checks}

\subsection{Control and treatment group assignment}

There are three types of players in our sample: (i) Europeans whose teams qualified for the Euro 2008, (ii) Europeans whose teams did not qualify for the Euro 2008, and (iii) non-Europeans for whom it was clear that their team would not participate in the Euro 2008 from the start. So far the control group included all players of type (ii) and (iii), i.e., all players whose national teams did not participate in the Euro 2008, while the treatment group included all players of type (i).

This gives rise to two potential concerns. First, one may be concerned that Europeans who participated in the qualification games for the Euro 2008 may have influenced their (treatment versus control) group assignment. Although a nation's participation in the Euro Cup qualification games is exogenous, and nationality is an exogenous characteristic of each player 46 a nation's qualification for the Euro 2008 should depend on the skills of the players who played in the qualification matches. For some European players, selection into the treatment group may thus not be completely random at this stage. Second, results could be driven by a "double treatment effect" whereby Europeans whose teams failed to qualify were discouraged after the qualification decisions, because they now faced worse future career prospects than they may have expected before.

As a first robustness check, we therefore run regressions using only non-Europeans as the control group (and Europeans of type (i) as the treatment group, as before). This ensures that all players in the control group were ineligible to play in the Euro 2008 for an exogenous reason. The regressions continue to include player fixed effects to control for (time-invariant) skill differences between players, which should further alleviate potential bias.

Results are consistent with our earlier findings using the full sample: the estimated treatment effect remains positive for players with medium selectchance values and negative

\footnotetext{
${ }^{46}$ Although not entirely impossible, players very rarely switch nationalities to be able to play for a different national team, partly because the FIFA has a critical attitude towards such steps.
} 
(and of nearly identical magnitude as before) for players with high selectchance values (see the first column of Table 11). Similarly, the findings of regressions with quadratic interactions between the treatment and selectchance are consistent with our earlier results (see Table 17 in the Appendix). These results give us confidence that our earlier findings were not solely driven by potential effects on Europeans whose teams failed to qualify.

We also test directly for the presence of a discouragement effect on European players whose teams failed to qualify for the Euro 2008. The second column in Table 11 present the findings of regressions in which the treatment group consist of Europeans whose teams did not qualify (group ii above) and the control group of non-Europeans (group iii above). The results are mixed. In our main regression specification, we do find a significant negative effect for players with low selectchance values, but no significant effects for players in the medium and high selectchance samples ${ }^{47}$ In the specification with quadratic interactions between the treatment and selectchance, none of the coefficients of interest are significant (see Table 17 in the Appendix). Overall, we thus find only weak evidence of a discouragement effect.

\subsection{Employment contracts}

A key institutional feature that our empirical analyses exploit is that European and nonEuropean players work for the same clubs. It is therefore natural to expect that treatment and control players face similar incentives aside from national team opportunities, and that (conditional on covariates) the performances of players in the two groups would have evolved similarly over time in the absence of the Euro Cup treatment, the key identification assumption underlying our empirical analyses.

Ideally, however, our regressions would also control for the terms of players' contracts including salaries, given that contracts (and market "structure" more broadly) vary from player to player ${ }^{48}$ Unfortunately, we were unable to obtain detailed data on contract terms, with the exception of expiration dates, which we collected from the magazine Kicker.

Clubs typically employ players under multi-year contracts. At contract expiration, which almost always occurs at the end of a season, ${ }^{49}$ players negotiate with their own and

\footnotetext{
${ }^{47}$ In regressions with four subsample based on selectchance quartiles, we find a significant negative effect for the second quartile.

${ }^{48}$ Recent theoretical work by Bonatti and Hörner (2013) explores the interplay between career concerns and market structure (in the form of wage-setting arrangements) in a dynamic context.

${ }^{49}$ In our dataset, all contract expirations occurred between seasons.
} 
Table 11: Robustness Checks

\begin{tabular}{|c|c|c|c|c|c|c|}
\hline & \multicolumn{6}{|c|}{ Dependent variable: performance index } \\
\hline & $\begin{array}{c}\text { Non-EU } \\
\text { control group }\end{array}$ & $\begin{array}{c}\text { Discourage } \\
\text { effect }\end{array}$ & $\begin{array}{c}\text { Contract } \\
\text { expirations }\end{array}$ & $\begin{array}{l}\text { Placebo } \\
\text { treatment }\end{array}$ & $\begin{array}{c}\text { Minutes } \\
\text { played > }\end{array}$ & $\begin{array}{l}\text { Tobit } \\
\text { MLE }\end{array}$ \\
\hline \multicolumn{7}{|l|}{ Low selectchance } \\
\hline euro $\times$ post & $\begin{array}{r}.07 \\
(.085)\end{array}$ & $\begin{array}{l}-.22^{* * *} \\
(.081)\end{array}$ & $\begin{array}{l}.20^{* *} \\
(.087)\end{array}$ & $\begin{array}{r}.07 \\
(.116)\end{array}$ & $\begin{array}{r}.08 \\
(.066)\end{array}$ & $\begin{array}{r}.15 \\
(.115)\end{array}$ \\
\hline injured & $\begin{array}{l}-.24 * * * \\
(.059)\end{array}$ & $\begin{array}{l}-.15 \\
(.115)\end{array}$ & $\begin{array}{l}-.22^{* * *} \\
(.066)\end{array}$ & $\begin{array}{l}-.32 * * * \\
(.076)\end{array}$ & $\begin{array}{l}-.12^{* *} \\
(.053)\end{array}$ & $\begin{array}{l}-.23^{*} \\
(.068)\end{array}$ \\
\hline homegame & ${ }_{(.019)}^{.13^{* * *}}$ & $\underbrace{.17^{* * *}}_{(.038)}$ & $\begin{array}{l}.15^{* * *} \\
(.020)\end{array}$ & $\begin{array}{l}.13^{* * *} \\
(.025)\end{array}$ & $\begin{array}{l}.16^{* * *} \\
(.018)\end{array}$ & $\underbrace{.12 * * *}_{(.021)}$ \\
\hline no. of observations & 6905 & 1570 & 5777 & 3541 & 5946 & 7124 \\
\hline \multicolumn{7}{|l|}{ Medium selectchance } \\
\hline euro $\times$ post & $\begin{array}{c}.26^{*} \\
(.143)\end{array}$ & $\begin{array}{l}-.18 \\
(.146)\end{array}$ & ${ }_{(.120)}^{.25^{* *}}$ & $\begin{array}{l}-.06 \\
(.125)\end{array}$ & ${ }_{(.086)}^{.18^{* *}}$ & $\begin{array}{l}.40^{* *} \\
(.175)\end{array}$ \\
\hline injured & $\begin{array}{l}-.22^{*} \\
(.112)\end{array}$ & $\begin{array}{l}-.11 \\
(.136)\end{array}$ & $\begin{array}{l}-.18^{*} \\
(.098)\end{array}$ & $\begin{array}{l}-.15 \\
(.138)\end{array}$ & $\begin{array}{l}-.15^{* *} \\
(.070)\end{array}$ & $\begin{array}{l}-.20^{*} \\
(.108)\end{array}$ \\
\hline homegame & $\underbrace{.19^{* * *}}_{(.035)}$ & $\begin{array}{l}.20 * * * \\
(.040)\end{array}$ & ${ }_{(.032)}^{.20^{* * *}}$ & $\begin{array}{l}.15^{* * *} \\
(.044)\end{array}$ & $\frac{.20 * * *}{(.033)}$ & ${ }_{(.211)}^{.21 * * *}$ \\
\hline no. of observations & 1549 & 1346 & 1785 & 1050 & 1835 & 2067 \\
\hline \multicolumn{7}{|l|}{ High selectchance } \\
\hline euro $\times$ post & $\begin{array}{l}-.33^{* * *} \\
(.106)\end{array}$ & $\begin{array}{r}.17 \\
(.117)\end{array}$ & $\begin{array}{l}-.29^{* * *} \\
(.081)\end{array}$ & $\begin{array}{r}.15 \\
(.097)\end{array}$ & $\begin{array}{l}-.27^{* * *} \\
(.050)\end{array}$ & $\begin{array}{l}-.38 * * * \\
(.126)\end{array}$ \\
\hline injured & $\begin{array}{l}-.31^{* * *} \\
(.110)\end{array}$ & $\begin{array}{l}-.32^{* * *} \\
(.104)\end{array}$ & $\begin{array}{l}-.35 * * * \\
(.095)\end{array}$ & $\begin{array}{l}-.22^{* * *} \\
(.077)\end{array}$ & $\begin{array}{l}-.31^{* * *} \\
(.086)\end{array}$ & $\begin{array}{l}-.30^{* * *} \\
(.087)\end{array}$ \\
\hline homegame & $\underset{(.030)}{.12^{* * *}}$ & ${ }_{(.027)}^{.12^{* * *}}$ & $\underset{(.030)}{.12^{* * *}}$ & $\begin{array}{c}.09^{*} \\
(.046)\end{array}$ & $\begin{array}{l}.15^{* * *} \\
(.025)\end{array}$ & ${ }_{(.027)}^{.12 * * *}$ \\
\hline no. of observations & 1730 & 904 & 1864 & 1068 & 2016 & 2125 \\
\hline
\end{tabular}

Notes: The table reports estimated coefficients for linear regression and marginal effects on the censored dependent variable for Tobit MLE. Values between parentheses are robust standard errors clustered at the player level. All specifications include player, gameday, field position, own club, and opponent club fixed effects. The subsamples Low, Medium, and High are drawn based on tertiles of selectchance for players with at least one national team selection, with selectchance cutoffs .29 and .91.

$* * *$ Significant at the 1 percent level.

** Significant at the 5 percent level.

*Significant at the 10 percent level.

other clubs. This may lead to a potential concern for our empirical analyses if players for whom we estimate a positive treatment effect are more likely to have their contracts expire in summer 2008 than other players, and an upcoming contract expiration creates positive incentive effects. Indeed, Stiroh (2007) finds that the performances of professional basketball players in the NBA improve in the year prior to contract expiration.

The third column in Table 11 reports regression results based on a sample excluding the 43 players whose contracts expired at the time of the Euro 2008. The findings are 
consistent with our main results, suggesting that incentives due to upcoming contract expirations did not confound our results.

One would also expect that, for some Europeans players, contract expiration dates and other unobserved contract characteristics (such as bonuses) may have been determined anticipating the incentive effects of the Euro 2008. Indeed, there is a significant negative correlation (equal to -.28 ) between the Euro 2008 career prospect treatment and contract expiration in summer 2008 in the high selectchance subsample 50 A potential explanation could be that the contract expiration dates for some top players were negotiated with the aim of lowering the reward from a Euro Cup participation and hence the adverse effect of the Euro Cup career prospect. As discussed, a strong performance in the Euro Cup often allows players to obtain higher-paid jobs after the tournament. Arguably, this reward to a Euro Cup participation is stronger for players whose current contract expires right after the Euro Cup than for others. By postponing contract expirations to a later date, managers may hence attempt to reduce the adverse incentive effect of an upcoming Euro Cup for players with very good chances.

\subsection{Placebo treatment}

A common concern with difference-in-differences estimation is that the estimated treatment effects might be spurious. To exclude this possibility, we run our main specification using data from earlier seasons (2005/06 and 2006/07) and setting a hypothetical start of the treatment period in November 2006, one year before the actual qualification decisions for the Euro 2008. The fourth column in Table 11 reports the results of these regressions. The estimated treatment effects are insignificant in all three selectchance subsamples, suggesting that our results are not spurious 51

\subsection{Left-censoring at zero minutes played}

Our empirical analyses so far ignored that our data are left-censored at zero. Soccer clubs employ between 20 and 30 players, but only a maximum of 14 players (11 starters and up to 3 substitutes) are on the field in any given game. Unless injured or otherwise unavailable, the remaining players spend the game on the reserve bench, which implies

\footnotetext{
${ }^{50}$ The corresponding correlations are insignificant in the low and medium selectchance samples.

${ }^{51}$ Consistent with this, we also find no significant treatment effects when dividing the players in four subsamples based on pastselect quartiles (see Online Appendix B).
} 
an observation of zero for all our performance measures. This is the case for $14 \%$ of observations in our full sample.

To investigate the impact of censoring on our findings, we first estimate our main specification excluding all observations associated with zero minutes played (minutes played > 0 ). The results, reported in the fifth column of Table 11, are consistent with our earlier findings, albeit the estimated treatments effects are smaller.

Second, we explicitly consider censored observations as corner solutions. Observed performance is still assumed to be linear in parameters, $Y_{i t}^{*}=\delta_{0}$ post $_{i t} \times$ euro $_{i}+\gamma_{i}+\alpha_{t}+$ $X_{i t}^{\prime} \beta+\varepsilon_{i t}$, but for estimation the dependent variable is now defined as $Y=\max \left[0, Y^{*}\right]$. The last column in Table 11 reports the findings of type 1 Tobit maximum likelihood estimation using this approach. Again, we find a significant positive treatment effect for players with intermediate values of selectchance and a significant negative treatment effect for players with high selectchance values, and the magnitudes of the estimated effects are similar to our earlier results.

\section{Conclusion}

This paper provides direct evidence that future career prospects create implicit incentives. Using data from professional soccer, we find that the career prospect of being selected to participate in an important upcoming Cup has economically important positive effects on the performances of players with intermediate selection chances, but economically important negative effects on the performances of players with high selection chances.

For players with intermediate chances of making their national team, our findings hence confirm that "...the increased rivalry benefits clubs, because players exert even higher effort in their clubs in order to get into the national team," as stated by Oliver Bierhoff, general manager of the German national team (Handelsblatt, 9/4/2009) ${ }^{52}$ However, our findings also suggest that an upcoming Cup is to the detriment of clubs that employ regular players of qualified national teams, because players who are already quite certain of being selected reduce their effort prior to the Cup to avoid fatigue and injuries. One can only speculate that statements such as "We want to ignite rivalry, and we want it for every position." (stern.de, 11/8/2004) by the German national team coach Joachim

\footnotetext{
${ }^{52}$ The original quote in German is “... der größer werdende Konkurrenzkampf bereichert auch die Vereine, weil die Spieler sich in ihren Klubs noch mehr anstrengen, um in die Nationalmannschaft zu kommen" (Handelsblatt, September 4th 2009; http://www.handelsblatt.com/magazin/fussball/ bierhoff-contra-allofs;2453190, accessed on 5 December 2014).
} 
Löw are meant to reassure clubs in this respect. ${ }^{53}$

Our findings have implications for the incentive effects of external career opportunities and promotion prospects in firms. Employees have incentives to increase or reduce effort for similar reasons as the professional soccer players in our data. Our empirical results suggest that effort incentives due to the promotion prospects will be strong for employees who believe that they have intermediate chances of getting promoted. Employees with very good chances of being promoted in the near future, on the other hand, may actually reduce their effort relative to a situation without any promotion prospect in order to avoid fatigue and thereby perform better once promoted.

\footnotetext{
${ }^{53}$ The original quote in German is "Wir wollen den Konkurrenzkampf entfachen, wir wollen ihn auf jeder Position haben." (stern.de, November 8th 2004; http://www.stern.de/sport/fussball/ nationalmannschaft-klinsmann-haelt-druck-fuer-torhueter-aufrecht-532041.html, accessed on 5 December 2014).
} 


\section{Appendix}

Table 12: Selectchance and actual Euro 2008 selections of euro group players

\begin{tabular}{|c|c|c|c|}
\hline Player & Nationality & Selectchance & Selected \\
\hline Hamit Altintop & Turkey & 1 & 1 \\
\hline Sotirios Kyrgiakos & Greece & 1 & 1 \\
\hline Joris Mathijsen & Netherlands & .998 & 1 \\
\hline Josip Simunic & Croatia & .998 & 1 \\
\hline Tomas Galasek & Czech Republic & .997 & 1 \\
\hline Theofanis Gekas & Greece & .997 & 1 \\
\hline Marcell Jansen & Germany & .996 & 1 \\
\hline Ioannis Amanatidis & Greece & .995 & 1 \\
\hline Jacek Krzynowek & Poland & .995 & 1 \\
\hline Rafael van der Vaart & Netherlands & .994 & 1 \\
\hline Bastian Schweinsteiger & Germany & .994 & 1 \\
\hline Per Mertesacker & Germany & .994 & 1 \\
\hline Thomas Hitzlsperger & Germany & .993 & 1 \\
\hline Torsten Frings & Germany & .992 & 1 \\
\hline Fernando Meira & Portugal & .992 & 1 \\
\hline Arne Friedrich & Germany & .989 & 1 \\
\hline Kevin Kuranyi & Germany & .988 & 1 \\
\hline Lukas Podolski & Germany & .977 & 1 \\
\hline Bernd Schneider & Germany & .973 & 0 \\
\hline Philipp Lahm & Germany & .973 & 1 \\
\hline Ivica Olic & Croatia & .971 & 1 \\
\hline David Jarolim & Czech Republic & .963 & 1 \\
\hline Piotr Trochowski & Germany & .914 & 1 \\
\hline Clemens Fritz & Germany & .875 & 1 \\
\hline Miroslav Klose & Germany & .857 & 1 \\
\hline Markus Rosenberg & Sweden & .845 & 1 \\
\hline Willy Sagnol & France & .828 & 1 \\
\hline Halil Altintop & Turkey & .808 & 0 \\
\hline Ivan Saenko & Russia & .732 & 1 \\
\hline Mario Gomez & Germany & .729 & 1 \\
\hline Simon Rolfes & Germany & .729 & 1 \\
\hline Nigel de Jong & Netherlands & .701 & 1 \\
\hline Roberto Hilbert & Germany & .534 & 0 \\
\hline Tim Borowski & Germany & .333 & 1 \\
\hline Gonzalo Castro & Germany & .327 & 0 \\
\hline Manuel Friedrich & Germany & .294 & 0 \\
\hline Ivan Klasnic & Croatia & .237 & 1 \\
\hline Hugo Almeida & Portugal & .201 & 1 \\
\hline Yildiray Basturk & Turkey & .162 & 0 \\
\hline Jiri Stajner & Czech Republic & .150 & 0 \\
\hline Jan Schlaudraff & Germany & .120 & 0 \\
\hline Patrick Owomoyela & Germany & .161 & 0 \\
\hline Jurica Vranjes & Croatia & .107 & 0 \\
\hline Mike Hanke & Germany & .104 & 0 \\
\hline Christian Pander & Germany & .069 & 0 \\
\hline Alexander Madlung & Germany & .046 & 0 \\
\hline Sebastian Kehl & Germany & .042 & 0 \\
\hline Gerald Asamoah & Germany & .041 & 0 \\
\hline Paul Freier & Germany & .036 & 0 \\
\hline Stefan Kiessling & Germany & .036 & 0 \\
\hline Mark van Bommel & Netherlands & .036 & 0 \\
\hline Sergiu Radu & Romania & .030 & 0 \\
\hline Vlad Munteanu & Romania & .030 & 0 \\
\hline Malik Fathi & Germany & .022 & 0 \\
\hline Patrick Owomoyela & Germany & .018 & 0 \\
\hline Fabian Ernst & Germany & .016 & 0 \\
\hline Christian Worns & Germany & .016 & 0 \\
\hline Heiko Westermann & Germany & 0 & 1 \\
\hline$\ldots$ & $\ldots$ & 0 & 0 \\
\hline
\end{tabular}


Table 13: Summary statistics: Subsamples stratified by selectchance

\begin{tabular}{|c|c|c|c|c|c|c|c|c|}
\hline & \multicolumn{4}{|c|}{ Pre-qualification } & \multicolumn{4}{|c|}{ Post-qualification } \\
\hline & \multicolumn{2}{|c|}{ euro } & \multicolumn{2}{|c|}{ non-euro } & \multicolumn{2}{|c|}{ euro } & \multicolumn{2}{|c|}{ non-euro } \\
\hline & Mean & S.d. & Mean & S.d. & Mean & S.d. & Mean & S.d. \\
\hline \multicolumn{9}{|c|}{ Low selectchance ( $N=7124,113$ euro and 34 non-euro players) } \\
\hline Age & 26.74 & 4.27 & 28.53 & 3.61 & & & & \\
\hline Selectchance & .03 & .04 & .04 & .05 & & & & \\
\hline Defense (dummy) & .36 & .48 & .44 & .50 & .39 & .49 & .42 & .50 \\
\hline Midfield (dummy) & .48 & .50 & .35 & .48 & .48 & .50 & .39 & .49 \\
\hline Forward (dummy) & .15 & .36 & .21 & .41 & .13 & .33 & .19 & .39 \\
\hline Game starter & .67 & .47 & .76 & .43 & .64 & .48 & .64 & .48 \\
\hline Minutes played & 60.03 & 37.33 & 67.98 & 33.28 & 58.08 & 38.48 & 59.72 & 37.29 \\
\hline Performance index & -.17 & .96 & .14 & .97 & -.21 & 1.00 & -.07 & 1.05 \\
\hline Passes received & 17.45 & 14.11 & 21.11 & 14.77 & 17.65 & 14.98 & 19.80 & 16.33 \\
\hline Ball contacts & 36.44 & 25.84 & 44.38 & 27.15 & 36.24 & 26.97 & 40.79 & 30.24 \\
\hline Shots on goal & .88 & 1.25 & 1.16 & 1.42 & .78 & 1.18 & .96 & 1.33 \\
\hline Goals & .07 & .28 & .10 & .34 & .08 & .28 & .08 & .30 \\
\hline Duels won & 8.15 & 6.36 & 9.96 & 6.08 & 7.98 & 6.36 & 8.36 & 6.38 \\
\hline Journalist grade & 1.72 & 1.21 & 2.01 & 1.17 & 1.63 & 1.23 & 1.77 & 1.28 \\
\hline Yellow/red card & .13 & .34 & .15 & .36 & .12 & .33 & .12 & .32 \\
\hline Fouls committed & 1.17 & 1.38 & 1.50 & 1.52 & 1.09 & 1.34 & 1.16 & 1.32 \\
\hline Fouls suffered & 1.08 & 1.41 & 1.39 & 1.51 & 1.07 & 1.41 & 1.12 & 1.41 \\
\hline \multicolumn{9}{|c|}{ Medium selectchance ( $N=2067,13$ euro and 26 non-euro players) } \\
\hline Age & 25.68 & 2.90 & 28.51 & 3.45 & & & & \\
\hline Selectchance & .71 & .19 & .65 & .21 & & & & \\
\hline Defense (dummy) & .22 & .41 & .31 & .46 & .18 & .39 & .29 & .45 \\
\hline Midfield (dummy) & .41 & .49 & .41 & .49 & .53 & .50 & .47 & .50 \\
\hline Forward (dummy) & .38 & .49 & .28 & .45 & .29 & .46 & .24 & .43 \\
\hline Game starter & .83 & .37 & .69 & .47 & .85 & .35 & .56 & .50 \\
\hline Minutes played & 74.49 & 27.25 & 61.52 & 35.56 & 74.68 & 25.70 & 52.63 & 38.21 \\
\hline Performance index & .32 & .90 & -.05 & 1.00 & .43 & .91 & -.28 & 1.03 \\
\hline Passes received & 24.33 & 13.66 & 19.54 & 14.51 & 27.66 & 15.23 & 17.80 & 15.54 \\
\hline Ball contacts & 44.41 & 23.38 & 37.90 & 25.97 & 47.62 & 24.88 & 33.66 & 27.31 \\
\hline Shots on goal & 1.45 & 1.58 & 1.10 & 1.37 & 1.63 & 1.56 & .88 & 1.32 \\
\hline Goals & .19 & .47 & .10 & .33 & .19 & .48 & .06 & .28 \\
\hline Duels won & 9.29 & 5.04 & 8.30 & 6.16 & 9.03 & 4.71 & 7.35 & 6.13 \\
\hline Journalist grade & 2.29 & 1.07 & 1.85 & 1.22 & 2.32 & 1.07 & 1.46 & 1.23 \\
\hline Yellow/red card & .13 & .33 & .13 & .34 & .13 & .33 & .10 & .30 \\
\hline Fouls committed & 1.31 & 1.37 & 1.32 & 1.43 & 1.16 & 1.20 & 1.15 & 1.37 \\
\hline Fouls suffered & 1.40 & 1.44 & 1.10 & 1.35 & 1.27 & 1.26 & 1.01 & 1.29 \\
\hline \multicolumn{9}{|c|}{ High selectchance ( $N=2125,22$ euro and 17 non-euro players) } \\
\hline Age & 27.84 & 3.54 & 29.55 & 2.79 & & & & \\
\hline Selectchance & .99 & .01 & .98 & .02 & & & & \\
\hline Defense (dummy) & .34 & .47 & .44 & .50 & .36 & .48 & .47 & .50 \\
\hline Midfield (dummy) & .44 & .50 & .44 & .50 & .40 & .49 & .46 & .50 \\
\hline Forward (dummy) & .22 & .42 & .12 & .33 & .23 & .42 & .07 & .25 \\
\hline Game starter & .91 & .28 & .84 & .37 & .83 & .38 & .86 & .35 \\
\hline Minutes played & 81.34 & 21.24 & 74.01 & 30.36 & 74.05 & 29.09 & 76.14 & 28.82 \\
\hline Performance index & .58 & .84 & .22 & 1.01 & .32 & .96 & .26 & .93 \\
\hline Passes received & 27.65 & 14.63 & 22.93 & 15.73 & 24.29 & 15.22 & 24.13 & 15.92 \\
\hline Ball contacts & 53.67 & 23.54 & 45.92 & 24.04 & 47.95 & 25.04 & 49.35 & 23.80 \\
\hline Shots on goal & 1.64 & 1.78 & 1.13 & 1.51 & 1.47 & 1.79 & .99 & 1.37 \\
\hline Goals & .17 & .43 & .14 & .38 & .144 & .43 & .12 & .35 \\
\hline Duels won & 11.14 & 5.25 & 9.88 & 5.69 & 9.48 & 5.44 & 9.89 & 5.16 \\
\hline Journalist grade & 2.51 & .97 & 2.15 & 1.12 & 2.23 & 1.18 & 2.25 & 1.05 \\
\hline Yellow/red card & .16 & .37 & .12 & .33 & .16 & .37 & .14 & .35 \\
\hline Fouls committed & 1.43 & 1.45 & 1.16 & 1.20 & 1.22 & 1.33 & 1.29 & 1.36 \\
\hline Fouls suffered & 1.58 & 1.66 & 1.68 & 1.84 & 1.19 & 1.31 & 1.55 & 1.66 \\
\hline
\end{tabular}

Notes: The subsamples Low, Medium, and High are drawn based on tertiles of selectchance for players with at least one national team selection, with selectchance cutoffs .29 and .91. Pre-qualification designates the time period prior to the official Euro 2008 qualification date. Player age is measured on 17 May 2008, the last game day preceding the Euro 2008. 
Table 14: Quadratic interactions: performance index and playing time

\begin{tabular}{|c|c|c|c|c|}
\hline & Lil & ar FE: sel & lance inters & \\
\hline & $\begin{array}{l}\text { Performance } \\
\text { index }\end{array}$ & Starter & $\begin{array}{l}\text { Minutes } \\
\text { played }\end{array}$ & $\begin{array}{c}\text { Index } \\
\text { per minute }\end{array}$ \\
\hline euro $\times$ post & $\begin{array}{r}.01 \\
(.089)\end{array}$ & $\begin{array}{r}.02 \\
(.044)\end{array}$ & $\begin{array}{r}1.57 \\
(3.538)\end{array}$ & $\begin{array}{l}-.04 \\
(.047)\end{array}$ \\
\hline$\times$ selectchance & $\begin{array}{l}3.12^{* * *} \\
(.927)\end{array}$ & $\begin{array}{l}1.14^{* *} \\
(.447)\end{array}$ & $\begin{array}{l}80.38^{* *} \\
(34.511)\end{array}$ & $\begin{array}{l}1.68^{* * *} \\
(.477)\end{array}$ \\
\hline$\times$ selectchance $^{2}$ & $\begin{array}{l}-3.48^{* * *} \\
(.933)\end{array}$ & $\begin{array}{l}-1.26^{* * *} \\
(.459)\end{array}$ & $\begin{array}{l}-91.30 * * * \\
(35.050)\end{array}$ & $\begin{array}{l}-1.76^{* * *} \\
(.489)\end{array}$ \\
\hline post & & & & \\
\hline$\times$ selectchance & $\begin{array}{l}-1.65^{* *} \\
(.682)\end{array}$ & $\begin{array}{l}-.75^{* *} \\
(.375)\end{array}$ & $\begin{array}{l}-55.37^{*} \\
(28.399)\end{array}$ & $\begin{array}{l}-.79^{* *} \\
(.366)\end{array}$ \\
\hline$\times$ selectchance $^{2}$ & $\begin{array}{l}1.86^{* * *} \\
(.687)\end{array}$ & $\left(.833^{* *}\right.$ & $\begin{array}{l}62.93^{* *} \\
(28.810)\end{array}$ & $\begin{array}{l}.85^{* *} \\
(.370)\end{array}$ \\
\hline midfield & $\begin{array}{l}-.25 * * * \\
(.087)\end{array}$ & $\begin{array}{l}-.19^{* * *} \\
(.042)\end{array}$ & $\begin{array}{l}-16.07 \text { *** } \\
(3.512)\end{array}$ & $\begin{array}{r}.03 \\
(.042)\end{array}$ \\
\hline forward & $\begin{array}{l}-.33^{* * *} \\
(.120)\end{array}$ & $\begin{array}{l}-.24^{* * * *} \\
(.061)\end{array}$ & $\begin{array}{l}-21.19 * * * \\
(4.778)\end{array}$ & $\begin{array}{r}.08 \\
(.064)\end{array}$ \\
\hline injured & $\begin{array}{l}-.22^{* * *} \\
(.043)\end{array}$ & $\begin{array}{l}-.10^{* * * *} \\
(.021)\end{array}$ & $\begin{array}{l}-7.69^{* * *} \\
(1.515)\end{array}$ & $\begin{array}{r}-.01 \\
(.034)\end{array}$ \\
\hline homegame & ${ }_{(.014)}^{.14^{* * *}}$ & $\begin{array}{r}-.007 \\
(.006)\end{array}$ & $\begin{array}{r}-.46 \\
(.417)\end{array}$ & $\begin{array}{l}.17^{* * *} \\
(.014)\end{array}$ \\
\hline no. of observations & 11316 & 11316 & 11316 & 9797 \\
\hline
\end{tabular}

Notes: The table reports linear fixed effects regression estimates. All specifications include player, gameday, own club, and opponent club fixed effects. Values between parentheses are robust standard errors clustered at the player level.

$* * *$ Significant at the 1 percent level.

**Significant at the 5 percent level.

*Significant at the 10 percent level. 
Table 15: Quadratic interactions: separate performance measures

\begin{tabular}{|c|c|c|c|c|c|c|}
\hline \multirow[b]{2}{*}{$N=11316$} & \multicolumn{6}{|c|}{ Linear FE: selectchance interactions } \\
\hline & $\begin{array}{l}\text { Passes } \\
\text { received }\end{array}$ & $\begin{array}{c}\text { Ball } \\
\text { contacts }\end{array}$ & $\begin{array}{l}\text { Shots } \\
\text { on goal }\end{array}$ & Goals & $\begin{array}{l}\text { Duels } \\
\text { won }\end{array}$ & Grades \\
\hline euro $\times$ post & $\begin{array}{r}-.35 \\
(1.261)\end{array}$ & $\begin{array}{r}-.09 \\
(2.361)\end{array}$ & $\begin{array}{l}.02 \\
(.103)\end{array}$ & $\begin{array}{r}-.002 \\
(.018)\end{array}$ & $\begin{array}{l}.57 \\
(.566)\end{array}$ & $\begin{array}{l}-.04 \\
(.103)\end{array}$ \\
\hline$\times$ selectchance & $\begin{array}{l}44.87^{* * *} \\
(12.566)\end{array}$ & $\begin{array}{l}68.85^{* * *} \\
(21.951)\end{array}$ & $\begin{array}{l}3.29^{* * *} \\
(1.107)\end{array}$ & $\begin{array}{l}.51^{* *} \\
(.250)\end{array}$ & $\begin{array}{c}8.23^{*} \\
(4.558)\end{array}$ & $\begin{array}{l}3.45^{* * *} \\
(1.040)\end{array}$ \\
\hline$\times$ selectchance $^{2}$ & $\begin{array}{l}-49.99 * * * \\
(12.834)\end{array}$ & $\begin{array}{l}-77.93^{* * *} \\
(22.409)\end{array}$ & $\begin{array}{l}-3.49^{* * *} \\
(1.122)\end{array}$ & $\begin{array}{l}-.56^{* *} \\
(.246)\end{array}$ & $\begin{array}{l}-10.67^{* *} \\
(5.567)\end{array}$ & $\begin{array}{l}-3.77^{* * *} \\
(1.057)\end{array}$ \\
\hline \multicolumn{7}{|l|}{ post } \\
\hline$\times$ selectchance & $\begin{array}{l}-22.38^{* *} \\
(9.354)\end{array}$ & $\begin{array}{l}-38.98^{* *} \\
(16.636)\end{array}$ & $\begin{array}{c}-1.16^{*} \\
(.691)\end{array}$ & $\begin{array}{l}-.26^{* *} \\
(.120)\end{array}$ & $\begin{array}{l}-3.95 \\
(3.540)\end{array}$ & $\begin{array}{l}-2.43^{* * *} \\
(.778)\end{array}$ \\
\hline$\times$ selectchance $^{2}$ & $\begin{array}{l}25.44 * * * \\
(9.489)\end{array}$ & $\begin{array}{l}44.47^{* * * *} \\
(16.969)\end{array}$ & $\begin{array}{l}1.32 * \\
(.672)\end{array}$ & $\left(_{(.119)}^{.27^{* *}}\right.$ & $\begin{array}{r}5.18 \\
(4.521)\end{array}$ & $\begin{array}{l}2.64^{* * *} \\
(.803)\end{array}$ \\
\hline midfield & $\begin{array}{l}-4.46^{* * *} \\
(1.099)\end{array}$ & $\begin{array}{l}-15.25^{* * * *} \\
(2.407)\end{array}$ & ${ }_{(.065)}^{.07 * * *}$ & $\begin{array}{l}.03^{* *} \\
(.011)\end{array}$ & $\begin{array}{l}-1.57^{* *} \\
(.652)\end{array}$ & $\begin{array}{l}-.33^{* * *} \\
(.100)\end{array}$ \\
\hline forward & $\begin{array}{l}-7.01 * * * \\
(1.615)\end{array}$ & $\begin{array}{l}-20.13^{* * *} \\
(3.131)\end{array}$ & $\begin{array}{l}.37^{* * * *} \\
(.118)\end{array}$ & $\begin{array}{l}.08^{* * * *} \\
(.021)\end{array}$ & $\begin{array}{l}-2.36^{* * *} \\
(.763)\end{array}$ & $\begin{array}{l}-.41^{* * *} \\
(.144)\end{array}$ \\
\hline injured & $\begin{array}{l}-2.42 * * * \\
(.564)\end{array}$ & $\begin{array}{l}-4.70^{* * *} \\
(1.010)\end{array}$ & $\begin{array}{l}-.25 * * * \\
(.065)\end{array}$ & $\begin{array}{l}-.04^{* * * *} \\
(.014)\end{array}$ & $\begin{array}{l}-1.09 * * * \\
(.269)\end{array}$ & $\begin{array}{l}-.18^{* * *} \\
(.054)\end{array}$ \\
\hline homegame & $\begin{array}{l}1.76^{* * *} \\
(.230)\end{array}$ & $\begin{array}{l}2.10^{* * * *} \\
(.356)\end{array}$ & ${ }_{(.021)}^{.22^{* * *}}$ & $\begin{array}{l}.02^{* * *} \\
(.006)\end{array}$ & ${ }_{(.095)}^{.26^{* * *}}$ & ${ }_{(.018)}^{.16^{* * *}}$ \\
\hline
\end{tabular}

Notes: The table reports linear fixed effects regression estimates. All specifications include player, gameday, own club, and opponent club fixed effects. Values between parentheses are robust standard errors clustered at the player level.

***Significant at the 1 percent level.

**Significant at the 5 percent level.

*Significant at the 10 percent level. 
Table 16: Quadratic interactions: destructive measures

\begin{tabular}{|c|c|c|c|}
\hline \multirow[b]{2}{*}{$N=11316$} & \multicolumn{3}{|c|}{ Linear FE: selectchance interactions } \\
\hline & $\begin{array}{c}\text { Yellow/Red } \\
\text { card }\end{array}$ & $\begin{array}{c}\text { Fouls } \\
\text { committed }\end{array}$ & $\begin{array}{c}\text { Fouls } \\
\text { suffered }\end{array}$ \\
\hline euro $\times$ post & $\begin{array}{r}.02 \\
(.019)\end{array}$ & $\begin{array}{l}.16 \\
(.100)\end{array}$ & $\begin{array}{l}.16 \\
(.105)\end{array}$ \\
\hline$\times$ selectchance & $\begin{array}{r}.26 \\
(.163)\end{array}$ & $\begin{array}{r}.03 \\
(.934)\end{array}$ & $\begin{array}{r}.63 \\
(.925)\end{array}$ \\
\hline$\times$ selectchance $^{2}$ & $\begin{array}{l}-.30^{*} \\
(.167)\end{array}$ & $\begin{array}{l}-.43 \\
(.982)\end{array}$ & $\begin{array}{l}-1.04 \\
(.928)\end{array}$ \\
\hline \multicolumn{4}{|l|}{ post } \\
\hline$\times$ selectchance & $\begin{array}{l}-.18^{*} \\
(.092)\end{array}$ & $\begin{array}{l}-.09 \\
(.751)\end{array}$ & $\begin{array}{r}.10 \\
(.691)\end{array}$ \\
\hline$\times$ selectchance $^{2}$ & ${ }_{(.099)}^{.21^{* *}}$ & $\begin{array}{r}.38 \\
(.773)\end{array}$ & $\begin{array}{l}-.02 \\
(.686)\end{array}$ \\
\hline midfield & $\begin{array}{r}-.001 \\
(.017)\end{array}$ & $\begin{array}{l}.004 \\
. .111)\end{array}$ & $\begin{array}{l}-.07 \\
(.137)\end{array}$ \\
\hline forward & $\begin{array}{l}-.04^{*} \\
(.023)\end{array}$ & $\begin{array}{l}-.08 \\
(.135)\end{array}$ & $\begin{array}{l}-.10 \\
(.164)\end{array}$ \\
\hline injured & $\begin{array}{l}-.01 \\
(.017)\end{array}$ & $\begin{array}{l}-.05 \\
(.060)\end{array}$ & $\begin{array}{l}-.08 \\
(.064)\end{array}$ \\
\hline homegame & $\begin{array}{l}-.03^{* * *} \\
(.006)\end{array}$ & $\begin{array}{l}-.13^{* * *} \\
(.023)\end{array}$ & $\begin{array}{l}.08 * * * \\
(.025)\end{array}$ \\
\hline
\end{tabular}

Notes: The table reports linear fixed effects regression estimates. All specifications include player, gameday, own club, and opponent club fixed effects. Values between parentheses are robust standard errors clustered at the player level.

***Significant at the 1 percent level.

** Significant at the 5 percent level.

*Significant at the 10 percent level. 
Table 17: Quadratic interactions: robustness checks

\begin{tabular}{|c|c|c|}
\hline & Linear FE: sel & lance interactions \\
\hline & $\begin{array}{l}\text { Non-EU } \\
\text { control group }\end{array}$ & $\begin{array}{l}\text { Discourage } \\
\text { effect }\end{array}$ \\
\hline euro $\times$ post & $\begin{array}{r}.01 \\
(.092)\end{array}$ & $\begin{array}{r}.26 \\
(.256)\end{array}$ \\
\hline$\times$ selectchance & $\begin{array}{l}2.35^{* *} \\
(1.150)\end{array}$ & $\begin{array}{l}-1.53 \\
(1.466)\end{array}$ \\
\hline$\times$ selectchance $^{2}$ & $\begin{array}{l}-2.56^{* *} \\
(1.169)\end{array}$ & $\begin{array}{r}1.83 \\
(1.369)\end{array}$ \\
\hline post & & \\
\hline$\times$ selectchance & $\begin{array}{r}-.86 \\
(.975)\end{array}$ & $\begin{array}{r}-.41 \\
(1.065)\end{array}$ \\
\hline$\times$ selectchance $^{2}$ & $\begin{array}{r}.92 \\
(.997)\end{array}$ & $\begin{array}{r}.55 \\
(1.058)\end{array}$ \\
\hline midfield & $\begin{array}{l}-.29 * * * \\
(.088)\end{array}$ & $\begin{array}{l}-.27 \\
(.172)\end{array}$ \\
\hline forward & $\begin{array}{l}-.35^{* * *} \\
(.126)\end{array}$ & $\begin{array}{l}-.27 \\
(.200)\end{array}$ \\
\hline injured & $\begin{array}{l}-.23^{* * *} \\
(.047)\end{array}$ & $\begin{array}{l}-.20 * * * \\
(.070)\end{array}$ \\
\hline homegame & $\begin{array}{l}.13^{* * *} \\
(.015)\end{array}$ & $\begin{array}{l}.17^{* * *} \\
(.024)\end{array}$ \\
\hline no. of observations & 10184 & 3820 \\
\hline
\end{tabular}

Notes: The table reports linear fixed effects regression estimates. All specifications include player, gameday, own club, and opponent club fixed effects. Values between parentheses are robust standard errors clustered at the player level.

***Significant at the 1 percent level.

**Significant at the 5 percent level. 


\section{References}

[1] Becker, Brian E. and Mark A. Huselid (1992), "The Incentive Effects of Tournament Compensation Schemes," Administrative Science Quarterly, Vol. 37, pp. 336-350.

[2] Bertrand, Marianne, Duflo, Esther, and Sendhil Mullainathan (2004), "How Much Should We Trust Differences-in-Differences Estimates?" Quarterly Journal of Economics, Vol. 119, No. 1, pp. 249-275

[3] Bonatti, Alessandro and Johannes Hörner (2013), "Career Concerns and Market Structure," Cowles Foundation for Research in Economics Discussion Paper No. 1831R, Yale University.

[4] Brown, Jennifer (2011), "Quitters Never Win: The (Adverse) Incentive Effects of Competing with Superstars," Journal of Political Economy, Vol. 119, No. 5, pp. 982-1013.

[5] Campbell, Dennis (2008), "Nonfinancial Performance Measures and PromotionBased Incentives," Journal of Accounting Research, Vol. 46, No. 2, pp. 297-332.

[6] Casas-Arce, Pablo and Asis Martinez-Jerez (2009), "Relative Performance Compensation, Contests, and Dynamic Incentives," Management Science, Vol. 55, No. 8, pp. 1306-1320.

[7] Chevalier, Judith A. and Glenn Ellison (1999), "Career Concerns of Mutual Fund Managers," Quarterly Journal of Economics, Vol. 114, No. 2, pp. 389-432.

[8] Chiappori, Pierre-Andre, Levitt, Steven D., and Timothy Groseclose (2003), "Testing Mixed-Strategy Equilibria When Players Are Heterogeneous: The Case of Penalty Kicks in Soccer," American Economic Review, Vol. 92, No. 4, pp. 1138-1151.

[9] Coupé, Tom, Smeets, Valérie, and Frédéric Warzynski (2006), "Incentives, Sorting and Productivity along the Career: Evidence from a Sample of Top Economists," Journal of Law, Economics, and Organization, Vol. 22, No. 1, pp. 137-167.

[10] Deutscher, Christian and Rob Simmons (2012), "The Economics of the World Cup," in: Kahane, L., Shmanske, S. (eds.): The Oxford Handbook of Sports Economics, Volumes I and II (Oxford University Press), pp. 449-469. 
[11] Dewatripont, Mathias, Jewitt, Ian, and Jean Tirole (1999a), "The Economics of Career Concerns, Part I: Comparing Information Structures," Review of Economic Studies, Vol. 66, No. 1, pp. 183-198.

[12] Dewatripont, Mathias, Jewitt, Ian, and Jean Tirole (1999b), "The Economics of Career Concerns, Part II: Application to Missions and Accountability of Government Agencies," Review of Economic Studies, Vol. 66, No. 1, pp. 199-217.

[13] Ederhof, Merle (2011), "Incentive Compensation and Promotion-Based Incentives of Mid-Level Managers: Evidence from a Multinational Corporation," The Accounting Review, Vol. 86, No. 1, pp. 131-153.

[14] Ehrenberg, Ronald G. and Michael L. Bognanno (1990), "Do Tournaments Have Incentive Effects?" Journal of Political Economy, Vol. 98, No. 6, pp. 1307-1324.

[15] Fama, Eugene (1980), "Agency Problems and the Theory of the Firm," Journal of Political Economy, Vol. 88, No. 2, pp. 288-307.

[16] Ferrer, Rosa (2008), "The Determinants of Weekly Hours of Work among Young Lawyers," working paper.

[17] Franke, Jörg (2012), "The Incentive Effects of Leveling the Playing Field - An Empirical Analysis of Amateur Golf Tournaments," Applied Economics, Vol. 44, No. 9, pp. 1193-1200.

[18] Frick, Bernd (2006), "Salary Determination and the Pay-performance Relationship in Professional Soccer: Evidence from Germany," in: Rodriguez, P., Kesenne, S., and J. Garcia (eds), Sports Economics After Fifty Years: Essays in Honour of Simon Rottenberg. Oviedo: Ediciones de la Universidad de Oviedo, pp. 125-46.

[19] Frick, Bernd (2007), "The Football Players' Labor Market: Empirical Evidence from the Major European Leagues," Scottish Journal of Political Economy, Vol. 54, No. 3, pp. $422-446$.

[20] Galinsky, Ellen, Bond, James T., Kim, Stacy S., Backon, Lois, Brownfield, Erin, and Kelly Sakai (2005). Overwork in America: When the way we work becomes too much, New York: Families and Work Institute. 
[21] Garicano, Luis and Ignacio Palacios-Huerta (2014), "Making the Beautiful Game a Bit Less Beautiful," In: Ignacio Palacios-Huerta, Beautiful Game Theory: How Soccer Can Help Economics, Princeton University Press, pp. 124-150.

[22] Ghosh, Suman and Michael Waldman (2010), "Standard Promotion Practices versus Up-or-Out Contracts," Rand Journal of Economics, Vol. 41, No. 2, pp. 301-325.

[23] Gibbons, Charles E., Suárez Serrato, Juan Carlos, and Michael B. Urbancic (2014), "Broken or Fixed Effects?" working paper, University of California, Berkeley.

[24] Gibbons, Robert and Kevin J. Murphy (1992), "Optimal Incentive Contracts in the Presence of Career Concerns," Journal of Political Economy, Vol. 100, No. 3, pp. 496-506.

[25] Hansen, Michael (2009), "How Career Concerns Influence Public Workers' Effort: Evidence from the Teacher Labor Market," CALDER Working Paper No. 40.

[26] Harbaugh, Rick and Tilman Klumpp (2005), "Early Round Upsets and Championship Blowouts," Economic Inquiry, Vol. 43, No. 2, pp. 316-329.

[27] Harrison, Yvonne and James A. Horne (2000), "The Impact of Sleep Deprivation on Decision Making: A Review," Journal of Experimental Psychology: Applied, Vol. 6, No. 3, pp. 236-249.

[28] Holmström, Bengt (1982/1999), "Managerial Incentive Schemes: A Dynamic Perspective," in: Essays in economics and management in honour of Lars Wahlbeck (Swenska Handelshogkolan, Helsinki, Finnland). Reprinted in: Review of Economic Studies (1999), Vol. 66, pp. 169-182.

[29] Hong, Harrison, Kubik, Jeffrey D., and Amit Solomon (2000), "Security Analysts' Career Concerns and Herding of Earning Forecasts," Rand Journal of Economics, Vol. 31, No. 1, pp. 121-144.

[30] Kleven, Henrik Jacobsen, Landais, Camille, and Emmanuel Saez (2013), "Taxation and International Migration of Superstars: Evidence from the European Football Market," American Economic Review, Vol. 103, No. 5, pp. 1892-1924.

[31] Knoeber, Charles R. and Walter N. Thurman (1994), "Testing the Theory of Tournaments: An Empirical Analysis of Broiler Production," Journal of Labor Economics, Vol. 12, No. 2, pp. 155-179. 
[32] Landers, Renee M., Rebitzer, James B., and Lowell J. Taylor (1996), "Rat Race Redux: Adverse Selection in the Determination of Work Hours in Law Firms," American Economic Review, Vol 86, No. 3, pp. 329-348.

[33] Lazear, Edward P. and Sherwin Rosen (1981), "Rank-Order Tournaments as Optimum Labor Contracts," Journal of Political Economy, Vol. 89, No. 5, pp. 841-864.

[34] Lazear, Edward P. (1989), "Pay Equality and Industrial Politics," Journal of Political Economy, Vol. 97, No. 3, pp. 561-580.

[35] Lucifora, Claudio and Rob Simmons (2003), "Superstar Effects in Sport: Evidence from Italian Soccer," Journal of Sports Economics, Vol. 4, pp. 35-55.

[36] Matros, Alexander (2006), "Elimination Tournaments Where Players Have Fixed Resources," University of Pittsburgh Working Paper No. 205.

[37] Meyer, Margaret A. (1991), "Learning from Coarse Information: Biased Contests and Career Profiles," Review of Economic Studies, Vol. 58, pp. 15-41.

[38] Meyer, Margaret A. (1992), "Biased Contests and Moral Hazard: Implications for Career Profiles," Annales d'Economie et de Statistique, Vol. 25/26, pp. 165-187.

[39] Miguel, Edward, Saiegh, Sebastián M., and Shanker Satyanath (2011), "Civil War Exposure and Violence," Economics and Politics, Vol. 23, No. 1, pp. 59-73.

[40] Nieken, Petra and Michael Stegh (2010), "Incentive Effects in Asymmetric Tournaments - Empirical Evidence from the German Hockey League," SFB/TR 15 Discussion Paper No. 305.

[41] O'Keeffe, Mary, Viscusi, W. Kip, and Richard J. Zeckhauser (1984), "Economic Contests: Comparative Reward Schemes," Journal of Labor Economics, Vol. 2, No. 1, pp. $27-56$.

[42] Orszag, Jonathan M. (1994), "A New Look at Incentive Effects and Golf Tournaments," Economics Letters, Vol. 46, No. 1, pp. 77-88.

[43] Palacios-Huerta, Ignacio (2003), "Professionals Play Minimax," Review of Economic Studies, Vol. 70, No. 2, pp. 395-415. 
[44] Prendergast, Canice and Lars Stole (1996), "Impetuous Youngsters and Jaded OldTimers: Acquiring a Reputation for Learning," Journal of Political Economy, Vol. 104, No. 6, pp. 1105-1134.

[45] Rosen, Sherwin (1982), "Authority, Control, and the Distribution of Earnings," Bell Journal of Economics, The RAND Corporation, Vol. 13, No. 2, pp. 311-323.

[46] Ryvkin, Dmitry (2011), "Fatigue in dynamic tournaments," Journal of Economics and Management Strategy, Vol. 20, No. 4, pp. 1011-1041.

[47] Stiroh, Kevin J. (2007), "Playing for Keeps: Pay and Performance in the NBA," Economic Inquiry, Vol. 45, No. 1, pp. 145-161.

[48] Sunde, Uwe (2009), "Potential, Prizes and Performance: Testing Tournament Theory with Professional Tennis Data," Applied Economics, Vol. 41, No. 25, pp. 3199-3208.

[49] Waldman, Michael (1984), "Job Assignments, Signalling, and Efficiency," Rand Journal of Economics, Vol. 15, No. 2, pp. 255-267.

[50] Waldman, Michael (2013), "Classic Promotion Tournaments versus Market-Based Tournaments," International Journal of Industrial Organization, Vol. 31, No. 3, pp. 198-210.

[51] Wooldridge, Jeffrey M. (2005), Unobserved Heterogeneity and Estimation of Average Partial Effects, In "Identification and Inference for Econometric Models: Essays in Honor of Thomas Rothenberg," eds. Donald Andrews and James Stock, Cambridge University Press. 